\title{
Inter-domain cooperation for mesoscale atmospheric laboratories: The Mesoscale Alpine Programme as a rich study case
}

\author{
Hans Volkert ${ }^{\mathrm{a} *}$ and Thomas Gutermann ${ }^{\mathrm{b}}$ \\ a Institut für Physik der Atmosphäre, DLR, Oberpfaffenhofen, Germany \\ ${ }^{\mathrm{b}}$ formerly MeteoSwiss, Zürich, Switzerland
}

\begin{abstract}
The development and conduct of the Mesoscale Alpine Programme (MAP) is summarized - a 10-year research initiative shared by meteorological services, research laboratories and university institutes from 14 countries. The overall investment is estimated to have exceeded 35 million Euros. Inventories are given of scientific results as published in some 220 peer-reviewed publications and over 40 completed $\mathrm{PhD}$ theses spanning a full decade. The close linkage between field measurements and various types of simulation experiments is emphasized by considering the role of natural laboratories (observing the atmosphere) and numerical laboratories (undertaking simulation experiments). Various forms of cooperation between laboratories and different domains such as nations, institutions and generations are used as the structuring elements of the survey. A comparison with surveys from other large field programmes helps to put the overall achievements of MAP into perspective. Copyright (c) 2007 Royal Meteorological Society
\end{abstract}

KEY WORDS mountain meteorology; mesoscale meteorology; field experiments; numerical weather prediction; scientific cooperation; THORPEX

Received 3 March 2007; Revised 11 April 2007; Accepted 16 April 2007

\section{Introduction}

About a century ago, academically trained physicists such as Napier Shaw and Vilhelm Bjerknes put considerable energy into the gradual conversion of the mainly descriptive discipline of meteorology to a proper science of atmospheric physics that also aimed at making predictions based on mathematically grounded theory. Bjerknes (1904) began by describing weather forecasting as an ambitious academic programme divided into the determination of the initial atmospheric state from observations (analysis) and its stepping forward in time through (graphical) integration of the governing equations (prognosis). Fifteen years later, months-long systematic observations from a mesoscale network of high spatial density inspired the concept of the Norwegian cyclone model (Bjerknes, 1919; Friedman, 1989, p.122).

Napier Shaw began his career as a gifted demonstrator, then lecturer and assistant director at the Cavendish Laboratory in Cambridge, where he used cloud chambers to mimic natural cloud formation and to deduce the vertical distribution of moisture above cloud systems (Shaw, 1895; Staley, 2006, p.101). Later, as director of the Meteorological Office and president of the International Meteorological Organization, Shaw organized the synthesis of

\footnotetext{
* Correspondence to: Hans Volkert, Institut für Physik der Atmosphäre, Deutsches Zentrum für Luft- und Raumfahrt (DLR), Oberpfaffenhofen, D-82234-Wessling, Germany. E-mail: hans.volkert@dlr.de
}

masses of data from atmospheric observations by physical methods, e.g. the calculation and depiction of cyclonescale surface trajectories (Shaw and Lempfert, 1906).

Nowadays meteorology is well established as atmospheric physics. Experiments in the laboratory are mostly replaced by numerical experimentation using simulation models. Field campaigns are frequently considered as experiments in the atmosphere's natural laboratory. But when looking back on the achievements of an international research initiative such as the Mesoscale Alpine Programme (MAP), the dichotomies between atmosphere and laboratory, and between experimental observation and theoretical analysis, appear to provide valuable perspectives, particularly when combined with the essential need for cooperation in meteorology. Shaw (1934, p. 119) expressed such an idea when he reminisced at the age of eighty:

Looking back, it occurs to me that, whether or not meteorology be really an inductive science, it is very liable to two failings arising from the fact that it is necessarily a cooperative enterprise; one's own observations at one time must be viewed in relation to other observations at the same or other times. The ordinary failings are not seeing the wood for the trees when one is making an experimental or mathematical investigation, and not seeing the trees for the wood when one is making a map; both must be in mind as different aspects of the same phenomenon. 
This survey has several interlinked aims:

(1) to briefly recall the evolution of MAP during the decade 1995-2005;

(2) to document the enterprise concisely in terms of input, i.e. financial resources, and output, such as publications and educational achievements;

(3) to highlight the voluntary cooperation between various domains such as nations, (classes of) institutions, generations, and individuals; and

(4) to properly place the bulk of achievements, most of them documented in this issue through eight in-depth review articles, within the overall success story of atmospheric physics during the past century.

Quite naturally the emphasis is put on mesoscale processes fitting the Alpine scale, i.e. on horizontal lengths between 2 and $2000 \mathrm{~km}$, grid sizes ranging between 0.5 and $50 \mathrm{~km}$, and time-scales from 1 to 1000 hours (about 40 days).

The study is cast into the following structure: section 2 recalls to what extent the planning of MAP could build on previous cooperation, and section 3 comprises various cooperative aspects within the physical world of the Alpine atmosphere. Section 4 collects different important interactive facets of simulation models which became relevant during the conduct of MAP. Section 5 refers to important MAP-specific structures that helped to couple the physical world with the virtual realities of simulation experiments and numerical weather forecasts. In the concluding section, MAP is put in perspective with past and ongoing research initiatives under the auspices of the WWRP. (Appendix D explains all acronyms.)

\section{Building on previous cooperation}

From its inception, MAP was considered as an integrated research programme which put the emphasis on mesoscale processes in the Alpine region and contained a field campaign as a central component. In a similar way, GARP (1967-1980; ICSU, 2006) had 'orographic effects' on its agenda during the 1970s. A collection of eleven review articles (Hide and White, 1980) set the global scene. Topics like 'structure, mechanism and prediction of orographically enhanced rain', 'mountain waves', 'modification of the planetary boundary layer' are still of high relevance today. Accordingly, the ALPEX was defined for coordinated observations of the modification of synoptic flows by the Alps as a whole. ALPEX was the last of a series of large international field campaigns within GARP; it consisted of a one-year general observation period containing a special observation period with enhanced measurements during March and April 1982 (Kuettner, 1986). The exploration of lee cyclogenesis over the northern Mediterranean proved to be a major area of scientific advance. As the desired deep cross-Alpine flows did not occur, alternative mountain-wave missions were flown across the neighbouring ranges of the Pyrenees and Dinaric Alps (bora flows). ALPEX participants from Switzerland, Austria and Germany formed the ALPEX regional group when GARP support diminished rapidly after 1982. The six-monthly ALPEX regional bulletin published by MeteoSwiss and annual scientific meetings kept some momentum and a group spirit that much assisted the early shaping of the next atmospheric science research initiative with the Alps as its geographical focus.

Another important root for MAP was PYREX, which had a two-month field phase in October and November 1990. Ten IOPs took place spanning 15 days altogether (Bougeault et al., 1997). Wave generation in crossmountain flow and local winds systems were measured and systematically simulated in hindcast mode. An intercomparison with 15 simulation models, some of them operational ones, hinted at systematic deficiencies such as the retarding effect of the discretized model orography being too small, leading to an overestimation of wave amplitudes (Georgelin et al., 2000). The entire programme was initiated by the meteorological services of France and Spain and later joined by partners from several other European countries.

According to LeMone (2003), large field campaigns typically undergo three phases: the pre-field phase containing the definition of scientific objectives, the selection of a proper name and acronym as well as the acquisition of funds; the (mostly short) field phase itself; and the post-field phase of data analysis and synthesis that often ends prematurely either due to insufficient funds, because of conflicting interests between the programme coordinator and individual investigators, or through pressure exerted by the planning of new projects. For the GATE in 1974, LeMone presented the number of related publications per year over a period of 25 years. It exhibits a distinct peak six years after the field campaign, but even 20 years later GATE data were used for fresh investigations. The use of models is treated separately from the three phases as models are nowadays used during all the planning, execution and analysis stages.

The MAP clearly lies within the tradition of large field campaigns such as those of GARP and described by LeMone. However it should be viewed from a wider perspective since

(1) it was conceived as a full research programme making use of existing, though separate, datasets and aiming at a multi-month coordinated experiment in the natural atmospheric laboratory;

(2) it developed into a most successful undertaking by obtaining funds from a large variety of sources in the different participating countries;

(3) it resulted in the production of a wealth of studies published in peer-reviewed journals; and

(4) it contributed to the academic education of many talented students who completed $\mathrm{PhD}$ theses dealing with various MAP aspects. 
Detailed figures on items (2) to (4) are given in the appendices and discussed in the following sections. LeMone's dichotomy of 'field programme' versus 'models' is transposed in this survey into a juxtaposition of two classes of physical laboratory: the natural laboratory of the real atmosphere (which simultaneously contains all acting processes at any given time), and the numerical laboratory of various simulation experiments (be they fully idealized, realistic in topography and with some processes turned on and others off, or as close as possible to reality as in NWP).

The scientific objectives of MAP were widely discussed at an international workshop at the ETH in Zurich in September 1994. (MAP Newsletter 1, 1994). In the MAP Design Proposal their combination was paraphrased as:

\section{The programme's coupled overall aim is to further our basic understanding and forecasting capabilities of the physical and dynamical processes that \\ - govern precipitation over major complex topography, and \\ - determine three-dimensional circulation patterns in the vicinity of large mountain ranges, and the strategy is to focus on key orography-related mesoscale effects that are exemplified in the Alpine region. (Binder and Schär, 1995)}

The planning phase of MAP lasted from 1995 to 1999. The field phase was termed the SOP and took place between 7 September and 15 November 1999. The analysis and synthesis phase lasted until 2005. A detailed description of the scientific objectives, the eight interlinked MAP projects (P1-P8), and preliminary results of the MAP SOP were given in Bougeault et al. (2001), and a special issue was subsequently published containing 25 articles synthesizing SOP observations, often with the help of numerical simulations (Bougeault et al., 2003).

We now turn to the various forms of cooperation for the Alpine natural laboratory which became effective during the conduct of MAP.

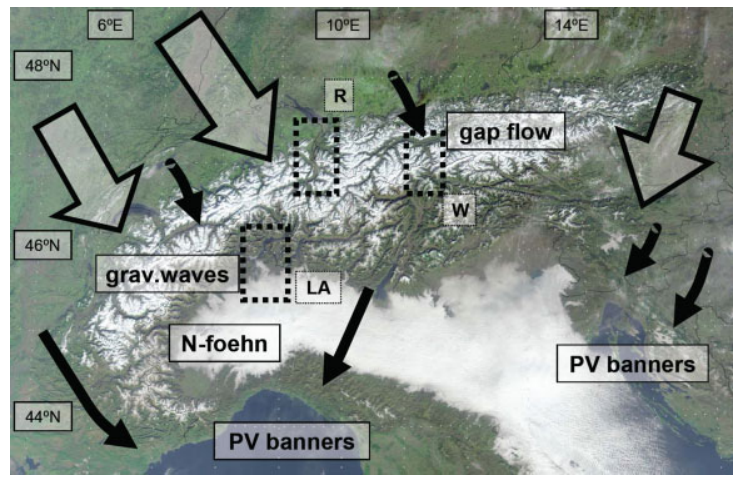

\section{Cooperation for the Alpine natural laboratory}

The atmospheric natural laboratory of the Alpine region exhibits a highly structured lower boundary surface composed of irregularly shaped massifs separated by deep long valleys. The curved structure of the entire massif and its predominantly west-east orientation induce a large and complex variety of low-level flows depending on the general direction of the impinging synoptic-scale flow in the free troposphere (Figure 1). The definition of the eight MAP projects reflects to a large degree the interests of academic research groups as well as of research departments of meteorological services. Early on, the latter stressed the high relevance of what became known as 'wet MAP', i.e. orographic precipitation mechanisms (P1) coupled with hydrological measurements and forecasts (P3) and frequently triggered by upper-tropospheric anomalies (P2). The former started by focusing on 'dry MAP', i.e. various dynamical aspects of flow over or around mountain complexes such as föhn in a large valley (P5), shooting flows through the narrow gap of a deep mountain pass ( $\mathrm{P} 4)$, the generation and eventual breaking of gravity waves (P6), the wake of single peaks or larger massifs as evidenced through low-level PV banners (P7), and the daily variation of the boundary layer in a steep valley (P8). During the MAP phases, however, a fruitful cross-fertilization took place between both camps, wet and dry, reflecting the fact that interesting cases for all MAP projects tend to happen over the Alps in close spatial and temporal proximity.

The first proposal for a research initiative called MAP was presented to the Informal Conference of Directors of Western European National Meteorological Services in April 1993 (Volkert et al., 1993). It pointed to the benefits of combining a number of items: to link scrutinized findings from existing datasets with the generation of better-resolved new ones; to bring together the developers of the next generation of mesoscale prediction models with modellers in academic environments; and to bring numerical experimentation in line with new observational

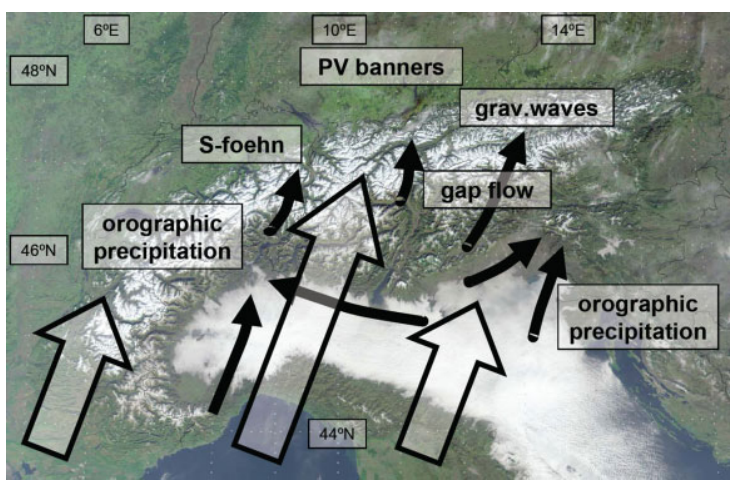

Figure 1. The Alpine natural laboratory in two schematic settings of upper-level synoptic-scale flows (wide arrows): predominant northerly (left) and southerly (right) components. Thin black arrows denote the related typical lower-level flows together with the regions where MAP projects like 'orographic precipitation' (P1), 'gap flow' (P4), 'gravity waves' (P6), 'PV-banners' (P7) were predominantly investigated. The dotted rectangles denote the target areas 'Lago Maggiore' (LA), 'Rhine Valley' (R), and 'Wipp Valley' (W), where enhanced networks of surface stations were installed during MAP SOP. The Alpine topography of irregular snow-covered massifs separated by long, deep and snow-free valleys is visualized by a cloud-free satellite scene (02 February 2002; MODIS instrument; on a stereographic projection). This figure is available in colour online at www.interscience.wiley.com/qj 
technologies. A list of scientific objectives was discussed at length during the above-mentioned MAP workshop in September 1994 and documented in the first version of the MAP design proposal (Binder and Schär 1995). Discussions following the Piedmont flood of November 1994 and strong recommendations from national services and WMO led to the integration of a hydrological project (P3) into MAP, which is documented in the second edition of the design proposal.

In this section we briefly outline how various committees paved the way to the SOP and beyond, how most valuable precipitation data were collected, quality controlled and publicized across political boundaries, how distributed operation centres helped to optimize the conduct of the SOP, how the community organized the overall scientific communication in a cooperative fashion, and how good luck in the natural laboratory helped to foster cooperation.

\subsection{Committees to prepare for the SOP}

At the first MAP meeting in June 1995, three MAP committees were inaugurated: the Inter-governmental Panel of senior officials from meteorological services and funding agencies to arrange for the core funding; the Scientific Steering Committee to coordinate and refine the various scientific objectives and plans; and the Coordination and Implementation Group to prepare key documents and to oversee the definition of target areas and the installation of operation centres. From the outset, the committee members exhibited a balanced mixture of meteorological services, research laboratories and university institutes (MAP Newsletter 3, 1995, p.7). Although the terms of reference for the three committees implied a hierarchical structure, the flow of information and preparation of decisions was often directed from the bottom to the top. An important result of this cooperation was the selection of three target areas (Figure 1) and three distributed operation centres.

The amount and timeliness of funding from a variety of national and international sources has an important impact for every large research programme. At the conclusion of MAP in 2005, overall figures were collected and they are given in Appendix A in an attempt to quantify the financial investment. The following general points are to be noted here:

(1) the overall investment over 10 years amounts to about 37 million $€$ (with an estimated uncertainty of $20 \%)$

(2) $43 \%$ of the funds were allocated to specific projects, $17 \%$ were invested for special infrastructure during the SOP, while the remaining $40 \%$ concerned in-kind investments for salaries and consumables paid by the participating institutions from their base budgets (this considerable amount is hard to estimate, but often not considered at all);

(3) the largest national shares came from the USA (36\%) and France (18\%), followed by Switzerland (13\%);
(4) a consortium of meteorological services established MAP as an optional project in their newly created EUMETNET initiative and contributed $6 \%$ of the funds, mainly to staff and to run a Programme Office and Data Centre. Besides the dry figures, the list of more than 20 funding agencies from 10 countries displays an impressive variety, the value of which is higher than the monetary contribution of the funds themselves; this will become apparent when the financial input is contrasted with the scientific and technological output of MAP.

As well as the committees, a number of working groups were formed for all the projects $\mathrm{P} 1-\mathrm{P} 8$, and also for radar networks, for Lidar instrumentation, for aircraft operations, for numerical modelling, for hydrological models, for the work of bench forecasters, and for a precipitation climatology. Over time, they acquired the highest importance for the conduct of MAP as they coordinated the basic work to be done in a flexible way, as is documented in the MAP Newsletters. The collection of precipitation data deserves extra attention as it ran in parallel to the preparation of the SOP, but had an important impact for the determination of the MAP season and the target areas.

In two countries, the MAP planning provided a considerable stimulus for cooperation on the national level. In the USA, scientists from university departments for atmospheric science and from civilian and naval meteorological services - NOAA and NRL - cooperated under the auspices of JOSS to produce a detailed planning document for their interactive participation in a field campaign in Europe (Houze et al., 1998). The distinguished chair for atmospheric sciences and international research (Kuettner) significantly aided the shaping of the US part of MAP from the accumulated campaign experience since GARP. In France, the research department of the meteorological service, research laboratories and university institutes integrated MAP topics within their multi-year national research programme on multi-scale issues in atmosphere and ocean (Bougeault et al., 2002).

\subsection{International collection of precipitation data}

The Alpine region houses several thousand rain-gauges with daily readings, resulting in (by far) the highest spatial density worldwide for an extended mountain range. The base data, however, are collected by a multitude of meteorological and hydrological agencies in six countries, often with responsibilities resting with authorities of smaller scale (such as states, regions, provinces and cantons). With MAP support from meteorological services, an institute of ETH Zurich took on the challenge of building up a consistent precipitation databank of daily resolution, of quality controlling all time series of multi-decadal length and of producing annual, seasonal, monthly or episode charts on a regular grid, similar to those used in operational NWP in the late 1990s. 


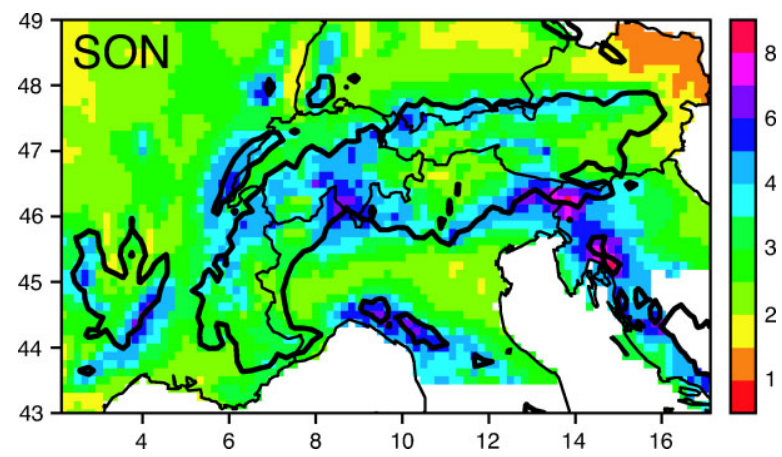

Figure 2. Mean daily precipitation $\left(\mathrm{mm} \mathrm{d}^{-1}\right)$ for the autumn months (September-November) from some 7500 daily time series for the period 1966-2000 aggregated on a $15 \times 15 \mathrm{~km}^{2}$ grid. Mountain ranges such as the Alps, the Massif Central, the Swiss Jura, the Black Forest and the Apennines are indicated by the bold $800 \mathrm{~m}$ height line (Courtesy of Christoph Frei; see also Frei and Schär, $1998^{\mathrm{B}}$ ). This figure is available in colour online at www.interscience.wiley.com/qj

As an example, the averaged daily precipitation amount for the autumn season (September-November) as obtained from 7500 daily time series from the period 1966-2000 is displayed in Figure 2. The aggregation onto a $15 \times 15 \mathrm{~km}^{2}$ grid reveals distinct maxima along the southern slopes of the Alps, the Apennines and the Cevennes Mountains in the Massif Central; preliminary results of this kind aided the decision to declare the Lago Maggiore region, shared by Switzerland and Italy, as a target area for the orographic precipitation project. Meanwhile the high-resolution Alpine precipitation climatology was inter alia used for the determination of seasonal averages and extremes (Frei and Schär, $1998^{\mathrm{B}}$ ), for publication in a regional hydrological atlas (Schwarb et al., 2001), for extreme events of rare occurrence (Frei and Schär, $2001^{\mathrm{B}}$ ), for testing daily series of global estimates (Rubel and Rudolf, 2001 ${ }^{\mathrm{B}}$ ) or of climate simulations for the Alpine region (Frei et al., 2003 ${ }^{\mathrm{B}}$ ). All references with the superscript ${ }^{B}$ can be found in Appendix B, a compact inventory of all reviewed MAP publications which appeared in print between 1997 and 2006. The reference list at the end of the paper contains only non-MAP references, some planning and overview documents and MAP-related special issues.

Networks of precipitation radars can be used qualitatively to determine size and life cycles of precipitation complexes at intervals of $0.5 \mathrm{~h}$. The planning phase of MAP provided an important stimulus for the formation of a European consortium during the 1990s. This project (HERA, 1996-1999; partly funded by the EU) also paved the way for technical developments, such as real-time radar composites (Hagen et al., 2000 ${ }^{\mathrm{B}}$ ), airborne Doppler radar (Georgis et al., 2000 ${ }^{\mathrm{B}}$ ) and non-hydrostatic simulation techniques including grid nesting and detailed microphysics (Stein et al., 2000 ${ }^{\mathrm{B}}$; Volkert, 2000).

When observations and simulations of precipitation in the atmosphere are to be realistically linked with hydrological forecasts, measurements of river run-off at gauges are needed as well as observations of soil moisture. All these strands were followed during the EUfunded project RAPHAEL (1998-2000) and applied, partly in real time, during MAP SOP (Bacchi et al., 2003).

Altogether, the planning phase of MAP provided numerous stimuli for international and inter-institutional cooperation. These efforts put together are of significance far beyond the aims of a field campaign. Now we focus on some cooperative aspects of the latter.

\subsection{Operation centres oversee non-routine measurements}

Field operations over a large area with mobile platforms (e.g. aircraft) and mission targets which vary greatly with the large-scale flow situation necessitate some centralization. During MAP SOP, a combined approach of three centres was applied after a careful decision process.

The Mission Operation Centre (MOC) was set up to the north of the Alpine divide at Innsbruck airport (Austria) and the student hostel next door. It hosted two tandems of scientific and operations directors (Bougeault/Dirks for the first half of the SOP, and Smith/Binder for the second half), their mission selection teams (4 members; typically on duty for 2-3 weeks), an international team of bench forecasters to brief the mission selectors about the current and foreseen weather situations over the extended Alpine region, the aircraft coordinator to negotiate all flights with the European air traffic control, the bulk of principal investigators to suggest the call of an IOP in conjunction with specific airborne missions, and the aircrews of the large US and UK research aircraft which used Innsbruck airport as their operational base. Furthermore, the specific operations in the nearby Wipp Valley Target Area were coordinated in the MOC. The daily routine followed a pre-established moving schedule containing forecasting, weather briefing, mission suggestion, mission selection, coordination with the other two operation centres and all the outstations, and debriefing depending on whether an IOP was to be called, was running or had just finished. The overall spirit was cooperative to enthusiastic; it resembled a theatre company on tour rather than a crowd of research groups with conflicting aims.

The Precipitation Operation Centre (POC) was situated in the military section of the airport Milano/Linate (Italy) south of the Alps and close to the Lago Maggiore Target Area where two large radar systems were deployed (Ronsard from France, S-Pol from the US). Specialists from the US and from France provided real-time guidance based on novel radar retrievals. The POC science coordinators (Rotunno and Houze) augmented the mission selection team and took part in the decision process by regular telephone conferences. Contacts with the Italian air traffic control were close and enabled in-flight modifications of flight plans following the motion of precipitation systems. The coordination between MOC and POC proved to run without major problems. 
For the bulk of extended ground-based observing systems and airborne missions in the Rhine Valley Target Area, a Co-operation Centre (COC) was set up in Bad Ragaz (Switzerland). Teams from Austria, France and Switzerland obtained from COC carefully selected frequencies for synchronous radiosonde ascents and also used it as a relay node for real-time data, which were then sent to the MAP Data Centre (MDC) in Zurich and the MOC in Innsbruck (cf. Richner et al. 2006 ${ }^{\mathrm{B}}$ ).

All in all, the partly decentralized structure of three operation centres with clearly assigned responsibilities proved to fit well both MAP's patchwork structure of scientific objectives and the geographical distribution of target areas. Modern communication tools, including numerous frequently updated web pages, turned out to be particularly useful.

3.4. Annual meetings to encourage cooperation and to advance science

The development and conduct of a multi-year research programme, mainly based on the voluntary cooperation of several hundred scientists, technicians and students, is in itself an experiment in group dynamics. Cooperation in committees can at best provide a solid backbone for a multitude of tasks that have to be undertaken, often in a quite explorative manner. From 1995 to 2001, a series of annual open science meetings proved to be most conducive for the enhancement of cooperation and the advance of science issues.

Always in late spring, the MAP meetings took place in small towns off the beaten track of science conferences and circled through the six Alpine countries: Bad Tölz (Germany) in 1995; Hall (Austria) in 1996; Belgirate (Lago Maggiore, Italy) in 1997; Chamonix (France) in 1998; Appenzell (Switzerland) in 1999; Bonhinjska Bistrica (Slovenia) in 2000, and Schliersee (Germany) in 2001. They lasted 1.5 to 2.5 days and were always combined with meetings of the MAP committees. Midafternoon poster sessions turned out to be a particularly strong asset with deeper and more vivid discussions than are possible during short presentations to the plenary.

The organization was provided by a small team of MAP participants of the country in charge. Modest prices enabled numerous students to participate, many of whom obtained invaluable input for the completion of their $\mathrm{PhD}$ theses (Appendix C gives a complete list). Extended abstracts of the majority of presentations appeared in MAP Newsletters 3 (1995), 5 (1996), 7 (1997), 9 (1998), 11 (1999), 13 (2000), and 15 (2001).

In October 1998 on the Monte Verità above Ascona, the full truth about the envisaged SOP was assembled during an international workshop termed 'Challenges in Mountain Meteorology' (MAP Newsletter 10, 1999, pp. 14-15). More than 70 participants from 11 countries cooperated under the stimulating organization of the atmospheric science institute of ETH. With Lago Maggiore in direct view, decisions were taken to allow the SOP to last for 10 weeks from 7 September 1999, to allocate some 600 flight hours of eight research aircraft to the various projects, and to finalize the MAP Implementation Plan.

Since 2002, MAP-related science topics feature prominently in the programmes of the biennial mountain meteorology conferences of the American Meteorological Society in even years and of the International Conferences on Alpine Meteorology which, for the purpose of transatlantic cooperation, was shifted to odd years in 2003 (after a regular schedule spanning 52 years). Many participants at all these regular meetings clearly felt that personal acquaintance with cooperation partners was an important root for common success, even in the era of fast global telecommunication networks. This human dimension should never be neglected or underestimated.

\subsection{Good luck in the natural laboratory fosters cooperation}

Working in the uncontrollable natural laboratory of the atmosphere carries the risk that, when the experimentalists are waiting, the desired weather situations do not occur at all or at least not with the envisaged intensity. When looking back, one realizes that in this respect MAP was struck by good luck in two respects.

During the time of the initial MAP planning workshop in Zurich in September 1994, there was considerable disagreement regarding the balance of the scientific objectives and the MAP season. An appreciable group of scientists favoured the study of Alpine convection, which implied choosing the spring and early summer season for the SOP (rather than the autumn). Two months later, the Piedmont flood caused dramatic loss of life and property. This united the developing MAP community to define a compatible set of scientific objectives, which became numbered P1 to P8 and loosely termed 'wet MAP' and 'dry MAP'.

The second stroke of good luck occurred during the field phase itself. The autumn of 1999 provided a highly attractive set of diverse cases exhibiting just the right intensity. The preceding autumn of 1998 was dominated by anticyclonic conditions with only a few weak situations of cross-Alpine flow (Steinacker, 1999). During the MAP season in 2000, the southern Alpine slopes were struck by a severe and widespread flood, which was so serious that it could have damaged some key equipment, would probably have exhausted the organizers' management and media skills, and may have jeopardized the conduct of the entire field experiment. The intermediate state of a harvest basket full of appealing fruit provided the best motivation for numerous and thorough analyses of the observed cases in the various numerical laboratories.

\section{Cooperation for non-hydrostatic numerical laboratories}

The realistic mapping of the transient atmosphere into a high-speed computer for skilful forecasting purposes constitutes a revolutionary advance of applied physics during 
the second half of the twentieth century (Lynch, 2002). By analogy with physical laboratories, numerical simulation models take on the role of numerical laboratories. In this section we inspect which kind of cooperation provided valuable incentives for the current development of a new generation of operational high-resolution mesoscale models for NWP, which do not impose the hydrostatic approximation but include a tendency equation for the vertical wind (i.e. non-hydrostatic models).

When MAP started in 1995, several meteorological services operated hydrostatic limited-area models with a horizontal grid size of about $15 \mathrm{~km}$ (e.g. ALADIN at Météo-France; DM/SM at DWD and MeteoSwiss; a version of the Unified Model at the UK Met Office; BOLAM at CNR, Italy). Non-hydrostatic models with grid-nesting facilities and the possibility of being driven by largerscale analyses were developed and applied mainly for research purposes (e.g. the PSU/NCAR mesoscale model (known as MM5) and COAMPS in the USA; MC2 in Canada; Meso-NH in France). The 16-fold zooming effect of a triple-nest configuration is exemplified in Figure 3, where the approximate outlines of mountain ranges like the Atlas, Pyrenees, and Alps become apparent in the outer domain $\left(3500 \times 3500 \mathrm{~km}^{2} ; 32 \mathrm{~km}\right.$ grid size), while Alpine massifs and valleys can be clearly distinguished on a $2 \mathrm{~km}$ grid.

The adequate incorporation of the irregular surface topography into simulation models poses conceptual difficulties, especially for steep and irregular terrain as in the Alpine region. For a proper treatment of precipitationproducing microphysical processes, sufficient realism and computational efficiency are competing targets. Although the refinements in such technical fields are outside the ordinary scope of a field campaign, various forms of cooperation during MAP provided important stimuli.

\subsection{Case-studies to refine novel approaches}

During the first half of the 1990s, several heavyprecipitation episodes in the autumn, causing severe flooding and casualties, underscored the need for improved regional predictions. The episodes were named after the most affected places (Vaison-la-Romaine, France, 20-22 September 1993; Brig, Switzerland, 20-28 September 1993; Piedmont, Italy, 4-6 November 1994; South Ticino, Switzerland, 13-14 September 1995) and were defined as common test cases in the working groups for numerical (atmospheric) modelling and for hydrological models.

Cooperative studies included thorough investigations of the most important physical processes (Buzzi et al., $\left.1998^{\mathrm{B}}\right)$, the role of tropopause anomalies as a trigger for precipitation (Massacand et al., $1998^{\mathrm{B}}$; Fehlmann and Quadri, $2000^{\mathrm{B}}$ ), and the combined impact of increased horizontal resolution and detailed cloud microphysics on the structure and strength of simulated precipitation (Stein et al., 2000 ${ }^{\mathrm{B}}$ ), the full coupling with hydrological models for river run-off (Bacchi and Ranzi, 2003 ${ }^{\mathrm{B}}$; Richard et al., $2003 \mathrm{a}^{\mathrm{B}}$ ). These cases were also central to EU-funded projects HERA and RAPHAEL. The geographical location and seasonal occurrence of these cases had a considerable impact on the selection of the period September-November for the SOP and the south Alpine focus for project P1.

Also, the realistic simulation of gravity wave events for mission planning was thoroughly tested through a broad model intercomparison for the well-documented Boulder windstorm (Doyle et al., 2000 ${ }^{\mathrm{B}}$ ). Prior to the SOP, the most promising measuring strategies for a multiple aircraft mission was tested by juxtaposing observations from a previous single-aircraft mission with 5 -fold-nested simulations down to a grid size of $0.56 \mathrm{~km}$ (Doyle et al., $2002^{\mathrm{B}}$ ).
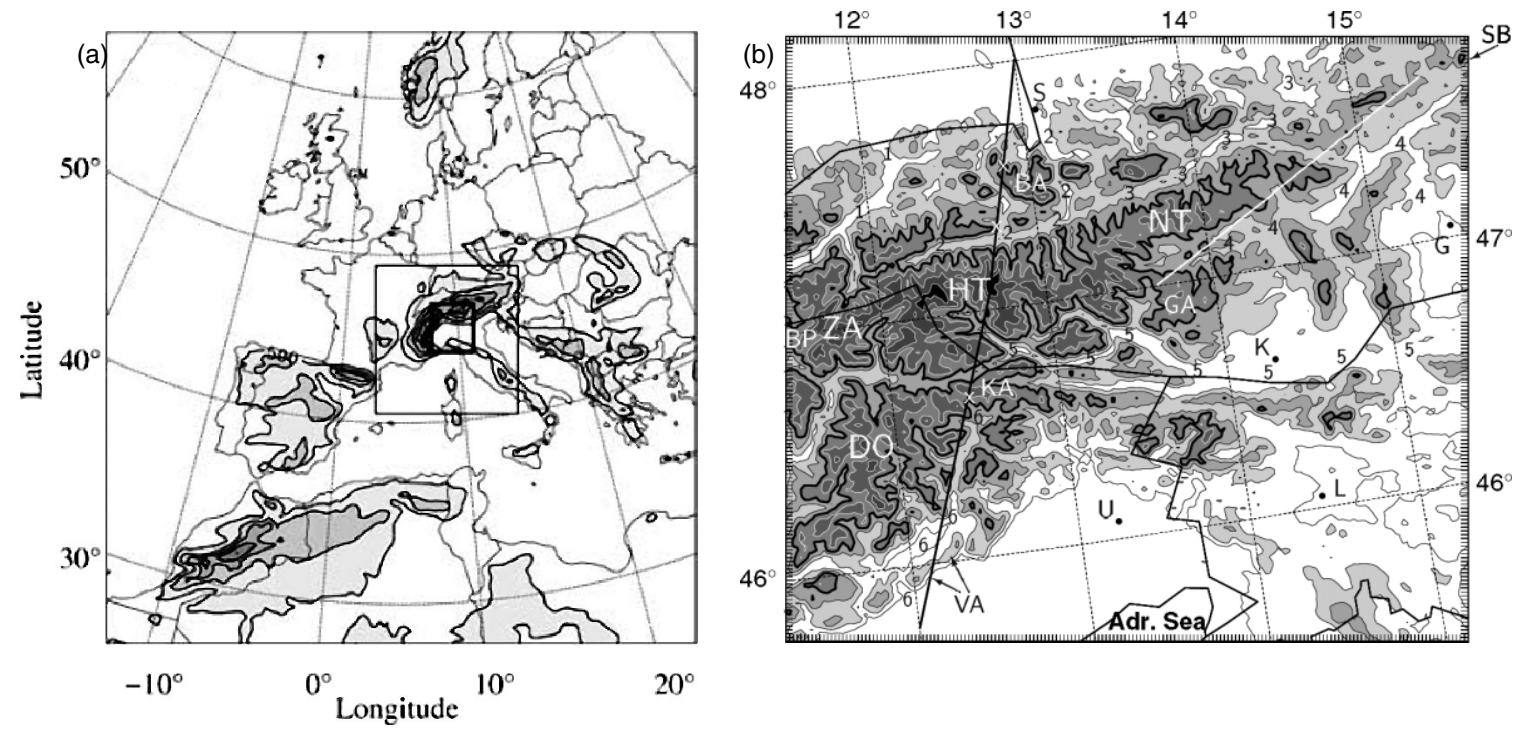

Figure 3. Geographical domains in two realizations of the Meso-NH non-hydrostatic numerical laboratory: (a) Triple-nested configuration for Europe, entire Alpine region and portion of southern Alpine flank, with horizontal mesh sizes of 32, 8 and $2 \mathrm{~km}$, respectively (with height contour increment $500 \mathrm{~m}$; from Lascaux et al., 2006 ${ }^{\mathrm{B}}$ ), and (b) detailed topography of the eastern Alps as seen by an inner grid with $2 \mathrm{~km}$ resolution (height contour increment $400 \mathrm{~m}$, with $1600 \mathrm{~m}$ line bold; from Volkert et al., $2003^{\mathrm{B}}$ ). 
4.2. Meteorological service interaction with academic institutions

The research departments of meteorological services are becoming increasingly aware that the development of their sophisticated simulation tools profits enormously when academic institutions, and $\mathrm{PhD}$ students in particular, apply them as true numerical laboratories for in-depth case-studies and for process studies with different degrees of idealization. During the decade of MAP, several such partnerships were initiated or further strengthened.

Using experiences from PYREX, Météo-France and the Laboratoire d'Aérologie started a joint project to develop a non-hydrostatic modelling system called Meso$\mathrm{NH}$, which is applicable for a range of scales from synoptic via meso down to small (or turbulent). In the meantime, it is used by the entire French research community and beyond (Richard et al., 2007, and references therein). It was also central to a number of MAP-related $\mathrm{PhD}$ theses completed in France (Appendix C).

The COAMPS of the US Navy was extensively applied for testing, forecasting and analysing gravity-wave cases, when a research partnership with Yale University proved to be very fruitful (Smith et al., 2007, and references therein). The non-hydrostatic Lokal-Modell (LM) of Deutscher Wetterdienst (DWD) delivered forecasts for mission guidance during its pre-operational phase which coincided with MAP SOP. Meanwhile, LM is being increasingly applied for research applications at DLR. It was also used to investigate predictability issues for different MAP SOP-inspired cases of orographically induced precipitation events (Hohenegger et al., 2006 ${ }^{\mathrm{B}}$ ).

Much motivated by pre-SOP MAP episodes, a research group in Bologna started in 2001 a further nonhydrostatic model development termed MOLOCH. This research tool was meanwhile applied to cases of orographic precipitation, to convection triggered by orography, and orographically influenced small-scale circulation systems. It took part in an international cooperation for comparative benchmarking, especially regarding quantitative precipitation forecasting (cf. Richard et al., 2007) and complements the efforts in high-resolution NWP within the COSMO consortium based on LM.

During the SOP, a cooperation between the Meteorological Service of Canada and ETH Zurich resulted in the first extended real-time application of a nonhydrostatic forecasting model on a $3 \mathrm{~km}$ grid covering the entire Alpine region. These forecasts provided valuable mission guidance during the SOP (Benoit et al., 2002). Later analyses also revealed systematic model deficiencies and pointed to ways they could be cured (Richard et al., 2007). Additionally the research-oriented Advanced Regional Prediction System (ARPS) and MM5 were frequently applied for MAP cases and for idealized investigations motivated by MAP observations dealing with convection and precipitation (e.g. Zängl, 2004 ${ }^{\mathrm{B}}$; Fuhrer and Schär, 2005 ${ }^{\mathrm{B}}$ ) as well as with gap flows

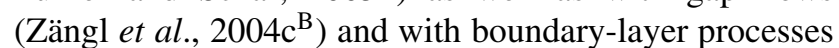
above steep terrain (Chow et al., 2006 ${ }^{\mathrm{B}}$; Weigel et al.,
$2006^{\mathrm{B}}$ ). Such modelling activities also triggered significant model improvements, such as a vertical coordinate formulation which improves the numerical accuracy of advection (Schär et al. $2002^{\mathrm{B}}$ ) or a treatment of horizontal numerical diffusion that minimizes systematic errors over steep topography (Zängl 2002 ${ }^{\mathrm{B}}$ ). A Met Office research group made extensive use of the gravity wave measurements during the SOP to calibrate and to adjust the operational wave drag scheme of the Unified Model at different resolutions (Smith and Broad, 2003 ${ }^{\mathrm{B}}$; Smith et al., 2006 ${ }^{\mathrm{B}}$; Smith et al., 2007).

In retrospect, the many cooperations between modelling teams from the services and from academic institutions during MAP appear impressive. They induced significant advances on a large number of detailed problems far beyond the immediate aims of a field experiment.

\subsection{Global reanalysis for mesoscale applications}

The provision of non-routine observational data with higher resolution in space and time constitutes a standard argument in favour of large field campaigns. A consistent integration of the bulk of extra observations into improved analyses of the evolving atmospheric state is quite a difficult enterprise. After the conduct of ALPEX it took more than ten years until the so-called Level IIIb datasets became available for the research community. Besides organizational post-campaign problems, this delay was also caused by the lack of an appropriate mesoscale analysis and forecasting system in the 1980s.

With this experience in mind, the MAP Steering Committee commissioned a complete reanalyis of the entire MAP SOP with a state-of-the-art data assimilation system in 2001. The MAP reanalysis (RA) was then carried out at ECMWF in two versions:

(1) with the global 4D-Var data assimilation scheme of 2001 (T511L60; 60 levels with about $40 \mathrm{~km}$ horizontal resolution) and the routine observations only; and

(2) as in (1), but with all appropriate SOP data included (mostly additional soundings, dropsoundings from research aircraft, and wind profiler data; Keil and Cardinali, 2004 ${ }^{\mathrm{B}}$ ).

The considerable impact which mountain ranges of mesoscale extent exert on the large-scale flow dynamics was reviewed by Schär (2002) with particular reference to MAP.

Mesoscale model hindcasts driven by the RA data did not always lead to improved 'predictions'. A closer inspection revealed subtle inconsistencies concerning the adjustment of flow and mass fields within the data assimilation and systematic biases with some of the data profiler data. Meanwhile the RA data were successfully used inter alia for quality checking atmospheric moisture retrievals through Global Positioning System occultation measurements (Bock et al., 2005 ${ }^{\mathrm{B}}$ ) and for a thorough evaluation 
of microphysical schemes during a variety of SOP precipitation episodes (Lascaux et al., 2006 ${ }^{\mathrm{B}}$ ).

The timely reanalysis of the entire SOP within three years after the field phase provided a strong overall justification for the combined field phase efforts. During future campaigns such a 'synoptic' value besides the specific science objectives could be enhanced still further, were meteorological services to put this task high on their research agenda and when truly mesoscale assimilation schemes are applied.

\section{Links between the different laboratories}

In the last two sections we considered the real atmosphere and non-hydrostatic simulation models separately as the scientific workshops or laboratories. Various links between these two categories have already became apparent. In this section three formal links are introduced, which are considered as essential for both the successful development of MAP and its enduring impact: the Programme Office, the Data Centre, and MAP-related publications.

\subsection{Programme Office}

Coordinated efforts within a large research programme necessitate an administrative backbone, which ideally is slim, flexible, but also strong. Right at the beginning of the MAP period, MeteoSwiss inaugurated the MAP Programme Office (PO) in January 1995 (MAP Newsletter 1, 1994, p. 12). A single scientific position was established that was shared by Peter Binder and Andrea Rossa, who continued their other obligations in the numerical modelling team of MeteoSwiss for the other half of their time. This solution of pragmatic simplicity continued for the full duration of MAP.

The tasks undertaken by the PO were numerous and various. In the early years it arranged for the timely publication of the MAP planning documents, i.e. the Design Proposal (1995, 1996), the Science Plan (1998), and the Implementation Plan (1999). Over the entire period the sessions of the MAP committees were prepared and monitored, and their decisions widely distributed. Progress within the different working groups was monitored and publicized for the community in order to facilitate cooperation between observation specialists and modellers. The importance of these tasks was recognized by the consortium of national weather services, which assisted MeteoSwiss to finance the PO through MAP-NWS, a voluntary EUMETNET project (Rossa, 2007).

In retrospect, is appears very fortunate that the PO was run by two scientists who worked in model development and application. Therefore they knew about the needs of colleagues from the MAP community from first-hand experience and better than full-time staff possessing only administrative backgrounds.

\subsection{Data Centre}

An immediate purpose of any field campaign is to collect data. In meteorology this means more data than those which are available from routine networks on a regular basis, data obtained with new instrumentation, or data which have not yet been put into a common geographical context. Right from the beginning, the MAP community built up the MAP Data Centre (MDC). MDC was hosted by the Institute of Atmospheric and Climate Science at ETH in Zurich until 2005 and is now archived by MeteoSwiss. Access by internet started straight away as described in Binder and Schär (1996, p. 57; current address: http://www.map.meteoswiss.ch).

The construction of the MDC and its filling with data was overseen by the MDC manager Hans Hirter. The MDC became filled step by step with routine data for the MAP seasons 1992-1999, with numerous observations concerning the twelve MAP episodes occurring between 1992 and 1996, surface measurements during the GOP (1 October 1998-31 December 1999), and eventually with the full catalogue of SOP observations. In cooperation with the JOSS, the latter was implemented at NCAR (Boulder, USA), which supervised the large US share of SOP operations.

The incorporation of routine observations from meteorological services to the MDC became possible after successful negotiations regarding the MAP data policy. This policy stipulates that all data acquired during the field campaign are freely accessible by all, and that at the same time data added to the MAP database coming from the archives of various organizations can still be under controlled access. Data are classified in various categories consistent with WMO Resolution 40, which early on was interpreted quite differently on both sides of the Atlantic. The MAP data policy was later adopted as the recommended model for all WWRP projects.

The MDC also houses a large collection of simulation results carried out by the working group on numerical modelling, including a systematic model intercomparison for IOP $2 b$ and numerous sample results from hindcasts of the MAP episodes preceding the SOP (Richard et al., 2007). These studies were mainly undertaken by academic institutions and profited from the various datasets at the MDC for model evaluations and the determination of skill scores. In this fashion the MDC provided strong and direct links between the natural and numerical laboratories.

The establishment of the MDC at an academic institution proved to be most beneficial as the data storage work before and during a field campaign is often more of an experimental nature than a sheer routine task. The geographical proximity to MeteoSwiss and the PO also helped to find pragmatic solutions for technical and administrative problems.

\subsection{Publications}

Cooperative actions like MAP necessitate formal publications, especially for discoveries and scientific findings. 
The internal communication during the programme was much aided by the above-mentioned planning documents and 20 issues of the MAP newsletter.

Cooperative aspects within formal publications become manifest, when research journals devote special issues to a certain topic. During the conduct of MAP no less than four such issues appeared. The findings of the EUfunded project HERA are collected in 14 articles in an issue of Meteorology and Atmospheric Physics (ten of them with a direct connection to MAP; Volkert, 2000). The outcome of the follow-on project RAPHAEL is documented in eleven papers in an issue of Hydrology and Earth System Sciences (five with direct relevance to MAP; Bacchi et al., 2003). A variety of MAP-related studies, which were first presented at the ICAM-2003 conference, appeared in three issues of Meteorologische Zeitschrift (Rossa et al., 2004).

Four years ago, findings from the SOP concerning all eight MAP projects $\mathrm{P} 1-\mathrm{P} 8$ appeared in 25 articles in the Quarterly Journal of the Royal Meteorological Society (Bougeault et al., 2003). Aspects of orographic precipitation were covered in 12 contributions. They concerned observations and the underlying physical processes (for which the current state of knowledge is reviewed by Rotunno and Houze, 2007), as well as their relevance for NWP in the future (with the latest review by Richard et al., 2007). Two contributions each were devoted to upper-tropospheric anomalies (current review by Hoinka and Davies, 2007), to hydrology for flood forecasting (now summarized by Ranzi et al., 2007), to the dynamics of gap flows (current state of the art by Mayr et al., 2007), to föhn in the Rhine Valley (now summarized by Drobinski et al., 2007), to three-dimensional gravity waves (put into perspective by Smith et al., 2007), and to potential vorticity banners. The final article dealt with the structure of the planetary boundary layer over steep terrain; Rotach and Zardi (2007) summarize the overall findings from MAP in this respect.

The Bulletin of the American Meteorological Society regularly publishes overviews dealing with field campaigns in general or technical innovations which were successfully demonstrated during a campaign. In the case of MAP, Chong et al. (2000) reported on the real-time wind retrievals obtained during the SOP in the Lago Maggiore Target Area, Bougeault et al. (2001) provided a broad overview of MAP and its SOP together with sample results from all MAP projects, Benoit et al. (2002) showed the value of the ultra-fine real-time model support for mission guidance provided by MC2 forecasts, and Rotach et al. (2004) synthesized measurements and simulations concerning turbulence and exchange processes in very steep terrain.

The complete harvest of MAP in terms of reviewed research journals is much richer still. A total of 220 papers in 30 journals was collected which made direct reference to the MAP Design Proposal (Binder and Schär, 1995), to the overview article about the SOP (Bougeault et al., 2001), or were known for technical preparations regarding observation or retrieval systems applied during the SOP. Their distribution over the years 1997 to 2006 is presented in Table I in a compact fashion, and the full inventory is given in Appendix B in order to make the selection transparent. These are the main conclusions:

(1) MAP results are treated equally in American and European research journals;

(2) the Quarterly Journal contains some 30\% of all MAP papers;

Table I. Distribution of 220 MAP related articles in peer-reviewed journals over the years 1997-2006 and 30 research journals. The journals are grouped by the publishing learned societies (AMS: American Meteorological Society; AGU: American Geophysical Union; RMS: Royal Meteorological Society; D-A-CH: consortium of meteorological societies of Germany, Austria, Switzerland; EGU: European Geophysical Union; IMI: International Meteorological Institute, Stockholm) or companies (Springer, Elsevier). The journal abbreviations are explained in the appendix, part B alongside the complete inventory of counted articles. Entries in bold contain the MAP related articles of the special issues in Meteorol. Atmos. Phys. 72, issue no. 2-4, 2000; Q. J. R. Meteorol.Soc. 129, issue no. 588, 2003; Hydrol. Earth System Sci. 7, issue no. 6, 2003; and Meteorol. Z. 13, issues no. 1-3, 2004.

\begin{tabular}{|c|c|c|c|c|c|c|c|c|c|c|c|c|}
\hline society/publisher & journal $(s)$ & $\begin{array}{c}\text { year } \\
97\end{array}$ & $\begin{array}{c}\text { year } \\
\mathbf{9 8}\end{array}$ & $\begin{array}{c}\text { year } \\
99\end{array}$ & $\begin{array}{c}\text { year } \\
\mathbf{0 0}\end{array}$ & $\begin{array}{c}\text { year } \\
\mathbf{0 1}\end{array}$ & $\begin{array}{c}\text { year } \\
\mathbf{0 2}\end{array}$ & $\begin{array}{c}\text { year } \\
\mathbf{0 3}\end{array}$ & $\begin{array}{c}\text { year } \\
04\end{array}$ & $\begin{array}{c}\text { year } \\
\mathbf{0 5}\end{array}$ & $\begin{array}{c}\text { year } \\
\mathbf{0 6}\end{array}$ & Sum \\
\hline \multirow[t]{3}{*}{ AMS } & JAS, MWR & & 2 & & 2 & 2 & 5 & 1 & 8 & 6 & 5 & 31 \\
\hline & JAOT, WF & & & & 3 & 6 & 3 & & 1 & & & 13 \\
\hline & BAMS, JAM, JC, JHyM & & & & 2 & 4 & 2 & 1 & 1 & 1 & 3 & 14 \\
\hline AGU & GRL, JGR & & 1 & 1 & & & & 4 & 1 & 1 & & 8 \\
\hline \multirow[t]{2}{*}{ RMS } & QJ & & & & & 4 & 5 & 30 & 11 & 7 & 10 & 67 \\
\hline & IJCli, MA & & 1 & & 1 & & 1 & & & & 1 & 4 \\
\hline D-A-CH & BPA, MZ & & & 2 & & 4 & 1 & 3 & 12 & & 1 & 23 \\
\hline EGU & ACP, AG, HESS & & & & 1 & & & 9 & & 1 & & 11 \\
\hline IMI & Tellus-A & & & & 1 & 1 & & 1 & 1 & & 1 & 5 \\
\hline Springer & AP-B, BLM, EFM, IA, MAP & 1 & & & 11 & 2 & 1 & 4 & 7 & 3 & 4 & 33 \\
\hline Elsevier & AE, JHyd, PCE & & & & 2 & 2 & 1 & 2 & 1 & & & 8 \\
\hline others & AsGs, Geof, HydP & & & & & & 1 & 2 & & & & 3 \\
\hline Sum & & 1 & 4 & 3 & 23 & 25 & 20 & 57 & 43 & 19 & 25 & $\underline{220}$ \\
\hline
\end{tabular}


(3) nearly $30 \%$ of the articles have an international co-authorship, i.e. the co-authors are affiliated to institutes in more than one country;

(4) the publication peak occurred in 2003 , about four years after the SOP; and

(5) the special issues mentioned above contribute significantly to the number of publications in their respective years.

LeMone (2003) reported a six-year time lag for the publication peak after the GATE campaign (1974); the speed-up by two years may be explained in part by wider use of electronic equipment for both data analysis and publication.

Theses submitted to obtain the academic degree of $\mathrm{DSc} / \mathrm{PhD}$ constitute a special class of publications. They are of relevance beyond their scientific content as they indirectly document the educational impact on the next generation of researchers. As detailed in Appendix C, no less than 45 young researchers graduated with MAP topics at universities of eight countries. They deal with both observational topics and issues of simulation and theory. Most of the students participated at MAP meetings or the follow-on science conferences, where they learnt to put their personal project into perspective and how to defend it against criticism of more experienced colleagues from outside their university environment. This educational component of MAP underscores the high importance of cooperation between academic institutions, research laboratories and meteorological services.

It is envisaged that the still-growing number of MAPrelated publications will in the long run constitute the main testimony of the tight links between natural and numerical laboratories. A significant number of more recent studies deal with both aspects side by side.

\section{Concluding remarks}

The MAP lasted for ten years and officially ended two years ago. What can generally be concluded besides the scientific findings that are reviewed in eight articles in this issue?

First, large research programmes including a multipurpose field campaign necessitate a deep breath. It takes several years to organize the various forms of cooperation, to attract sufficient funding, and to sharpen the scientific objectives. Second, such an enterprise is costly. Even if the total investment is difficult to quantify, we suggest putting the estimated investment from many sources (some $37 \mathrm{M} €$ over ten years; Appendix A) in relation to the annual budget of ECMWF (about $47 \mathrm{M} €$ ), to the development of all EUMETSAT satellite application facilities (about $35 \mathrm{M} €$ over 5 years), or to the overall cost of the European geostationary satellite MSG (some $2500 \mathrm{M} €$ ). Whatever conclusion interested parties may draw, these apparently different initiatives are also interlinked and can be viewed from a synoptic perspective. For instance, MAP research used rapid scans from
Meteosat (e.g. Smith et al., 2002 ${ }^{\mathrm{B}}$; Volkert et al., 2003 ${ }^{\mathrm{B}}$ ), and ECMWF relies on external research efforts like MAP to improve its modelling systems (Woods, 2006, p. 219). Third, strong two-way links becoming established between observation and simulation, and between the natural and the numerical laboratories, tend to stimulate a significant number of scientific findings, which in their entirety constitute progress. Cooperative connections between domains such as countries (possibly on different continents), institutions (such as services, laboratories, universities), and generations (experienced researchers and technicians in concert with able and ambitious students) tend to deliver most valuable synergetic spin-offs.

When WMO established its WWRP in 1998, MAP was solicited as the first WWRP research and development project. One concrete result of MAP will be the WWRP forecast demonstration project D-PHASE, which aims at a multi-month demonstration of probabilistic hydrological and atmospheric simulation of flood events in the Alpine region and can be regarded as the fourth phase of MAP (http://www.map.meteoswiss.ch/map-doc/dphase/ dphase_info.htm). An ongoing WWRP research and development project termed 'Convection and Orographically-induced Precipitation Study' (COPS; http://www. uni-hohenheim.de/spp-iop) directly uses the partnerships and findings established during MAP. Meanwhile, WWRP carries a global initiative under the umbrella of THORPEX. The experience gained during the conduct of MAP and collected here should be valuable for such cooperative enterprises in the future.

Funding agencies are increasingly asking for statistics which substantiate their investment in retrospect. Surveys such as this one are scarce in the formal literature. The review by LeMone (2003) is based on numerous field campaigns starting from GATE (1974), but it originated from the personal perspective of a jubilee volume for a distinguished colleague. The more recent FASTEX programme (with a field phase in 1997) is documented in detail in a special issue (Browning et al., 1999); a retrospective survey after a longer time span is not available to date. Both IMPROVE campaigns profited from experiences made during (wet) MAP; to date they are documented in a compact overview publication (Stoelinga et al. 2003) and numerous detailed investigations.

This survey distinguishes essentially three categories of financial input, and publications including $\mathrm{PhD}$ theses as scientific output. But it also demonstrates that the 'black box' of a research programme contains a multitude of aspects, where 'cooperation' can provide a useful guideline. A clear view of such cooperative mechanisms is important. Stephan Nelson, a NSF program director, mentioned explicitly the "visibility of a complete research programme, a strong programme office, and a first rate data centre' as facets that persuaded US agencies to invest in MAP in the late 1990s. He concluded in 2005: 
I guess success came from good planning from both the sponsoring agencies and the scientists. MAP was an extremely well-organized and well-run program. It could serve as a model for any large atmospheric sciences program.

Napier Shaw's words of 1934 (quoted in the introduction) motivated us to use 'cooperation' as a natural concept when reviewing a research programme like MAP. They also prompted us to apply the dichotomy between the laboratories of the real atmosphere and of computer models. Following his imaginative words once more, we are confident that MAP scientists could well see the wood with the trees, when they looked at details of their measurements, and the trees with the wood, when they inspected simulation details on computer-generated weather maps. And in the future all those who are interested in the mechanisms of atmospheric research programmes are invited to inspect MAP as a fascinating study case - as rich in facets as the Alpine atmosphere itself.

\section{Acknowledgements}

Accounting activities necessitate cooperation. Valuable input, especially for the tables in the appendices, was provided by Peter Binder, Philippe Bougeault, Andrea Buzzi, Reinhold Busen, Jean Coté, James Doyle, Dale Durran,
Heinz Finkenzeller, Cyrille Flamant, Giuseppe Frustaci, Sigrid Gärtner, Robert Houze, Branka Ivancan-Picek, Nicolas Kouwen, Yuh-Lang Lin, Georg Mayr, Stephen Mobbs, Stephan Nelson, Fritz Neuwirth, Laurenz Niel, Jože Rakovec, Roberto Ranzi, Evelyne Richard, Andrea Rossa, Mathias Rotach, Christoph Schär, Ronald Smith, Samantha Smith, Reinhold Steinacker, Jürgen Steppeler, Marc Žagar and Günther Zängl. Words of encouragement and of caution came from Huw Davies, Klaus-Peter Hoinka, Joachim Kuettner, Margaret LeMone, Manfred Reinhardt, Evelyne Richard and Ulrich Schumann. Philippe Bougeault, Andrea Buzzi, Günther Zängl and, in particular, Christoph Schär helped to strengthen the original manuscript with insightful comments. George Craig and QJ editor Peter Read supervised our foreigners' use of English. Jana Freund assisted the build-up and control of the publication inventory. All this support full of 'MAP spirit' is acknowledged with grateful appreciation.

\section{Appendix A}

Financial input

The overall financial investment of a large and diverse research programme is very difficult to assess. At the

Table A I. Investments for MAP made by countries and international bodies divided into project funds, extra investment (mostly for infrastructure during the SOP), and estimated in-kind investment from the base budgets of the participating institutions.

\begin{tabular}{|c|c|c|c|c|c|}
\hline $\begin{array}{l}\text { Country or } \\
\text { international body }\end{array}$ & Sponsoring agencies ${ }^{1}$ & $\begin{array}{c}\text { Project } \\
\text { funds }(\mathrm{M} €)\end{array}$ & $\begin{array}{c}\text { Extra } \\
\text { investment }(\mathrm{M} €)\end{array}$ & $\begin{array}{c}\text { In-kind } \\
\text { investment } \\
\text { (M€; estim.) }\end{array}$ & Total $(\mathrm{M} €)$ \\
\hline Austria & Fed. Min., FWF, ZAMG & 1.4 & $0.3^{\mathrm{a}}$ & 0.7 & 2.4 \\
\hline Canada & MSC, NRC & 0.1 & - & 0.2 & 0.3 \\
\hline Croatia & DHMZ & 0.1 & $0.1^{\mathrm{b}}$ & 0.1 & 0.3 \\
\hline France & CNRS, Météo-France, CNES, EDF & 1.0 & $1.0^{\mathrm{c}}$ & 4.9 & 6.9 \\
\hline Germany & DLR, DFG, DWD & 0.4 & $0.4^{\mathrm{d}}$ & 1.3 & 2.1 \\
\hline Italy & CNR, AMI & 1.1 & $0.6^{\mathrm{e}}$ & 0.6 & 2.3 \\
\hline Slovenia & ARSO & 0.1 & $0.1^{\mathrm{b}}$ & 0.1 & 0.3 \\
\hline Switzerland & SNF, MeteoSwiss, CSCS, ETH & 3.3 & - & 1.5 & 4.8 \\
\hline United Kingdom & Met Office, NERC & 0.1 & $0.3^{\mathrm{f}}$ & 0.7 & 1.1 \\
\hline United States & NSF, ONR, NCAR & 7.2 & $1.4^{\mathrm{h}}$ & 4.8 & 13.4 \\
\hline EUMETNET & National Meteorological Services & - & $2.2^{\mathrm{i}}$ & - & 2.2 \\
\hline European bodies & EU, ECMWF & $1.4^{\mathrm{j}}$ & - & $0.1^{\mathrm{k}}$ & 1.5 \\
\hline Total & & 16.2 & 6.4 & 15.0 & 37.6 \\
\hline
\end{tabular}

\footnotetext{
${ }^{a}$ Basic contribution to run the mission operation centre (MOC) in Innsbruck during SOP.

${ }^{\mathrm{b}}$ Enhancement of routine measurements.

${ }^{\mathrm{c}}$ Basic costs for SOP deployments.

${ }^{\mathrm{d}}$ Basic costs for research aircraft and enhanced observations.

${ }^{\mathrm{e}}$ Basic contribution for the precipitation operation centre (POC) in Milano and for enhanced measurements.

${ }^{\mathrm{f}}$ Deployment of research aircraft.

${ }^{\mathrm{g}}$ USA figures where provided in US\$; $1 \mathrm{US} \$=1 €$ is used as average conversion rate for the MAP period.

${ }^{\mathrm{h}}$ Basic costs for US MAP-office and field deployments (e.g. two research aircraft, Doppler radar).

${ }^{\mathrm{i}} 14$ national meteorological services contributed to basic infrastructure (e.g. programme office, data centre) via EUMETNET administered by MeteoSwiss.

${ }^{\mathrm{j}} \mathrm{EU}$ contribution to the MAP-related research projects HERA and RAPHAEL.

${ }^{\mathrm{k}}$ ECMWF contribution to reanalysis costs in addition to EUMETMET payment.

${ }^{1}$ See Appendix D for acronyms.
} 
end of the MAP period in 2005, reliable overall estimates were requested from the national representatives in three categories:

(1) direct project funds which are typically administered by such agencies as the NSF in the USA or the SNF in Switzerland;

(2) extra investments which were mainly used to set up the basic infrastructure for the SOP in autumn 1999; these include the set-up of various operation centres and the deployment of multi-user equipment such as aircraft or radar installations; and

(3) the considerable contribution of in-kind investments, which are carried by the participating institutions mainly through salaries of their fixed personnel and consumables from their base budgets.

Although the estimates for the latter category stem from different accounting systems in the various countries, the consolidated figures and explanatory notes given in Table A I are thought to provide useful orders of magnitude for the variety of investments made for MAP.

\section{Appendix B}

MAP-related research articles: Inventory 1997-2006

Research articles in peer-reviewed journals continue to be a basic form of deliverable after any scientific project. To underpin the global figures given in Table I, all counted articles are listed here in an abbreviated form; this enables the entire community to check and possibly update the inventory. The foremost formal requirement for an article to be included in the inventory is that it refers to the MAP design proposal (Binder and Schär, 1995, 1996) or the MAP SOP overview by Bougeault et al. (2001); it has been confirmed that all studies helped the preparation of MAP SOP, used data from MAP SOP, or took inspiration from MAP SOP observations for theoretical investigations.

Table B I lists the 30 journals with their publishing body, and then Table B II shows the 220 articles which appeared in print during the decade 1997-2006, by year and alphabetically by lead author. The page range provides some indication of the size of the investigation.

Table B I. List of journals with publishing society or company. The acronyms in brackets are used in Table I.

\begin{tabular}{ll}
\hline Journal & Publisher \\
\hline Ann. Geophys. (AsGs) & Instituto Nationale di Geofisica, Italy \\
Annales Geophysicae (AG) & European Geophysical Union (EGU) \\
Appl. Phys. B (AP-B) & Springer \\
Atmos. Chem. Phys. (ACP) & European Geophysical Union \\
Atmos. Environ. (AE) & Elsevier \\
Beitr. Phys. Atmos. (BPA) & Deutsche Meteorologische Gesellschaft (DMG) \\
Boundary-Layer Meteorol. (BLM) & Springer \\
Bull. Am. Meteorol. Soc. (BAMS) & American Meteorological Society (AMS) \\
Environ. Fluid Mech. (EFM) & Springer \\
Geofizika (Geof) & Geophysical Institute, Zagreb \\
Geophys. Res. Lett. (GRL) & American Geophysical Union (AGU) \\
Hydrol. Earth System Sci. (HESS) & European Geophysical Union \\
Hydrol. Processes (HydP) & Wiley InterScience \\
Int. J. Climatol. (IJCli) & Royal Meteorological Society (RMS) \\
Integr. Assess. (IA) & Springer \\
J. Appl. Meteorol. (JAM) & American Meteorological Society \\
J. Atmos. Oceanic Technol. (JAOT) & American Meteorological Society \\
J. Atmos. Sci. (JAS) & American Meteorological Society \\
J. Climate (JC) & American Meteorological Society \\
J. Geophys. Res. (JGR) & American Geophysical Union \\
J. Hydrol. (JHyd) & Elsevier \\
J. Hydrometeorol. (JHyM) & American Meteorological Society \\
Meteorol. Appl. (MA) & Royal Meteorological Society \\
Meteorol. Atmos. Phys. (MAP) & Springer \\
Meteorol. Zeitschrift (N. Folge) (MZ) & D-A-CH \\
Mon. Weather Rev. (MWR) & American Meteorological Society \\
Phys. Chem. Earth B (PCE) & Elsevier \\
Q. J. R. Meteorol. Soc. (QJ) & Royal Meteorological Society \\
Tellus A & International Meteorological Institute, Stockholm (IMI) \\
Weather and Forecasting (WF) & American Meteorological Society \\
\hline & \\
\hline & \\
\hline &
\end{tabular}

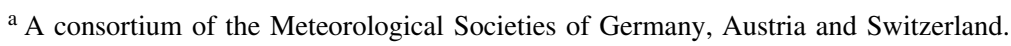


Table B II. MAP-related publications by year. *denotes co-authorship from institutions in more than one country (61 of 220 papers or $28 \%$ ).

\section{7}

Heimann. Meteorol. Atmos. Phys. 62: 49-70

\section{8}

Äbischer and Schär. J. Atmos. Sci. 55: 186-207

Buzzi et al. Mon. Weather Rev. 126: 2369-2383

Frei and Schär. Int. J. Climatol. 18: 873-900

Massacand et al. Geophys. Res. Lett. 25: 1435-1438

\section{9}

Ehret et al. J. Geophys. Res. 104: 31351-31359

Morgenstern and Davies. Beitr. Phys. Atmos. 72: 173-186

Schmid and Dörnbrack. Beitr. Phys. Atmos. 72: 287-301

\section{0}

Buzzi and Foschini. Meteorol. Atmos. Phys. 72: 131-146

Cacciamani et al. Meteorol. Atmos. Phys. 72: 147-159

Chong and Cosma. J. Atmos. Oceanic Technol. 17, 1556

*Chong et al. Bull. Am. Meteorol. Soc. 81: 2953-2962

*Doyle et al. Mon. Weather Rev. 128: 901-914

Fehlmann et al. Weather and Forecasting 15: 4-28

Fehlmann and Quadri. Meteorol. Atmos. Phys. 72: 223-231

${ }^{*}$ Ferretti et al. Tellus 52: 161-179

Frei et al. Integr. Assess. 1: 281-299

*Georgis et al. Meteorol. Atmos. Phys. 72: 185-202

Germann and Joss. Phys. Chem. Earth B 25: 903-908

*Hagen et al. Meteorol. Atmos. Phys. 72: 87-100

James et al. Weather and Forecasting 15: 327-338

Jansa et al. Meteorol. Appl. 7: 323-333

Keil and Volkert. Meteorol. Atmos. Phys. 72: 161-173

*Mladek et al. Meteorol. Atmos. Phys. 72: 111-129

Pellarin et al. Phys. Chem. Earth B 25: 953-957

Petitdidier et al. Phys. Chem. Earth B 25: 1195-1199

Scheidereit and Schär. Meteorol. Atmos. Phys. 72: 233-250

Stein et al. Meteorol. Atmos. Phys. 72: 203-221

Steinacker et al. Mon. Weather Rev. 128: 2303-2316

Vignal et al. J. Appl. Meteorol. 39: 1715-1726

Volkert. Meteorol. Atmos. Phys. 72: 73-85

\section{1}

*Baumann et al. Atmos. Environ. 35: 6379-6390

*Bougeault et al. Bull. Am. Meteorol. Soc. 82: 433-462

Caccia et al. Meteorol. Zeitschrift 10: 469-478

${ }^{*}$ Chong and Bousquet. Meteorol. Atmos. Phys. 78: 133-139

*Drobinski et al. Boundary-Layer Meteorol. 99: 277-296

Frei and Schär. J. Climate 14, 1568-1584.

*Furger et al. J. Atmos. Oceanic Technol. 18, 1975-1988

Germann and Joss. J. Appl. Meteorol. 40: 1042-1059

Houze et al. Q. J. R. Meteorol. Soc. 127: 2537-2558

James and Houze. J. Atmos. Oceanic Technol. 18: 1674-1683

Lin et al. Weather and Forecasting 16: 633-660

Marsigli et al. Q. J. R. Meteorol. Soc. 127: 2095-2115

Massacand et al. Mon. Weather Rev. 129: 2822-2828

Menziani et al. Phys. Chem. Earth B 26: 431-436

Miglietta and Buzzi. Tellus 53: 481-499

Molteni et al. Q. J. R. Meteorol. Soc. 127: 2069-2094

*Piringer et al. Meteorol. Zeitschrift 10: 445-455

* Reitebuch et al. J. Atmos. Oceanic Technol. 18: 1331-1344

*Rotunno and Ferretti. J. Atmos. Sci. 58, 1732-1749

*Rubel and Rudolf. Meteorol. Zeitschrift 10: 407-418

Ruffieux and Stübi. Meteorol. Zeitschrift 10: 489-495
Schmidli et al. J.Climate 14: 3289-3306

Sprenger and Schär. Q. J. R. Meteorol. Soc. 127, 161-187

Tabary and Scialom. J. Atmos. Oceanic Technol. 18,1293-1314

*Tabary et al. J. Atmos. Oceanic Technol. 18: 875-882

\section{2}

${ }^{*}$ Benoit et al. Bull. Am. Meteorol. Soc. 83: 85-109

${ }^{*}$ Cassardo et al. Hydrol. Processes 16: 1275-1299

${ }^{*}$ Cherubini et al. Weather and Forecasting 17: 238-249

Cosma et al. Q. J. R. Meteorol. Soc. 128: 75-92

*Doyle et al. Q. J. R. Meteorol. Soc. 128: 2175-2184

*Flamant et al. Q. J. R. Meteorol. Soc. 128: 1173-1210

Germann and Joss. J. Appl. Meteorol. 41, 542-557.

Germann and Zawadzki. Mon. Weather Rev. 130: 2859-2873

Gheusi and Stein. Q. J. R. Meteorol. Soc. 128: 337-360

Jasper et al. J. Hydrol. 267: 40-52

Mayr et al. J. Atmos. Oceanic Technol. 19: 1545-1556

65 Poberaj et al. Appl. Phys. B 75: 165-172

Pradier et al. Mon. Weather Rev. 130: 2533-2553

${ }^{*}$ Rubel et al. Meteorol. Zeitschrift 11: 367-370

Schär et al. Mon. Weather Rev. 130: 2459-2480

Schmidli et al. Int. J. Climatol. 22: 1049-1074

${ }^{*}$ Smith et al. J. Atmos. Sci. 59: 2073-2092

Tabary and Petitdidier. J. Atmos. Oceanic Technol. 19: 875-887

Zängl. Q. J. R. Meteorol. Soc. 128: 431-450

Zängl. Mon. Weather Rev. 130: 1423-1432

\section{3}

Ahrens. Meteorol. Zeitschrift 12: 245-255

Ahrens. Annales Geophysicae 21: 627-637

Asencio et al. Q. J. R. Meteorol. Soc. 129: 565-586

Bacchi and Ranzi. Hydrol. Earth System Sci. 7: 785-798

Balestri et al. Ann. Geophys. 46: 197-203

Bencetić et al. Geofizika 20: 23-61

Benoit et al. Hydrol. Earth System Sci. 7: 877-889

Bolliger et al. Meteorol. Zeitschrift 12: 73-80

Bousquet and Smull. Q. J. R. Meteorol. Soc. 129: 391-409

Bousquet and Smull. J. Appl. Meteorol. 2: 1497-1513

Buzzi et al. Q. J. R. Meteorol. Soc. 129: 1795-1818

Corazza et al. Meteorol. Atmos. Phys. 83: 131-143

*Dabas et al. Geophys. Res. Lett. 30: 1049, 21, 1-4

Doyle and Smith. Q. J. R. Meteorol. Soc. 129: 799-823

*Drobinski et al. Boundary-Layer Meteorol. 106: 483-505

*Drobinski et al. Q. J. R. Meteorol. Soc. 129: 729-753

Durran et al. Q. J. R. Meteorol. Soc. 129: 693-713

Faccani et al. Mon. Weather Rev. 131: 136-154

Ferretti et al. Q. J. R. Meteorol. Soc. 129: 587-607

${ }^{*}$ Frei et al. J. Geophys. Res. 108: ACL 9, 1-19

${ }^{*}$ Frioud et al. Atmos. Environ. 37: 17855-1797

Georgis et al. Q. J. R. Meteorol. Soc. 129: 495-522

Gheusi and Stein. Q. J. R. Meteorol. Soc. 129: 1819-1840

Grossi and Falappi. Hydrol. Earth System Sci. 7: 920-936

${ }^{*}$ Hagen and Yuter. Q. J. R. Meteorol. Soc. 129: 477-493

*Hoinka et al. Q. J. R. Meteorol. Soc. 129: 609-632

Ivančan-Picek et al. Meteorol. Zeitschrift 12: 103-112

Jasper and Kaufmann. Q. J. R. Meteorol. Soc. 129: 673-692

Jaubert and Stein. Q. J. R. Meteorol. Soc. 129: 755-776

Jiang. Tellus 55: 301-316

Jiang et al. Q. J. R. Meteorol. Soc. 129: 857-875

Kaufmann et al. Hydrol. Earth System Sci. 7: 812-832

Liniger and Davies. Q. J. R. Meteorol. Soc. 129: 633-651 
Table B II. (Continued).

Lothon et al. Q. J. R. Meteorol. Soc. 129: 2171-2193 Matzinger et al. Q. J. R. Meteorol. Soc. 129: 877-895 Medina and Houze. Q. J. R. Meteorol. Soc. 129: 345-371 Menziani et al. Hydrol. Earth System Sci. 7: 890-902 * Montaldo et al. Hydrol. Earth System Sci. 7: 848-861 Pullen et al. J. Geophys. Res. 108: 3320, 18,1-20 Ranzi et al. Q. J. R. Meteorol. Soc. 129: 653-672 ${ }^{*}$ Reitebuch et al. Q. J. R. Meteorol. Soc. 129: 715-727

*Richard et al. (a). Q. J. R. Meteorol. Soc. 129: 543-563

*Richard et al. (b). Hydrol. Earth System Sci. 7: 799-811

*Rotunno and Ferretti. Q. J. R. Meteorol. Soc. 129: 373-390

Ross and Vosper. Q. J. R. Meteorol. Soc. 129: 97-115

*Schär et al. Q. J. R. Meteorol. Soc. 129: 825-855

Seity et al. Q. J. R. Meteorol. Soc. 129: 523-542

Smith. J. Hydrol. 282: 2-9

${ }^{*}$ Smith et al. Q. J. R. Meteorol. Soc. 129: 433-454

Smith and Broad. Q. J. R. Meteorol. Soc. 129: 2195-2216

Soula et al. J. Geophys. Res. 108, ACL 10, 1-17

*Steiner et al. Q. J. R. Meteorol. Soc. 129: 411-431

van Gorsel et al. Boundary-Layer Meteorol. 109: 311-329

*Volkert et al. Q. J. R. Meteorol. Soc. 129: 777-797

Yuter and Houze. Q. J. R. Meteorol. Soc. 129: 455-476

Zängl. Meteorol. Atmos. Phys. 83: 237-261

Zappa and Gurtz. Hydrol. Earth System Sci. 7: 903-919

\section{4}

Baumann and Piringer. Meteorol. Atmos. Phys. 85: 125-139

Baumann and Groehn. Meteorol. Zeitschrift 13: 131-142

Beck and Ahrens. Meteorol. Zeitschrift 13: 55-62

Beffrey et al. Q. J. R. Meteorol. Soc. 130: 541-560

Beffrey et al. Meteorol. Zeitschrift 13: 77-82

Belušić and Klaić. Tellus 56: 296-307

Bolliger et al. Meteorol. Atmos. Phys. 87: 219-234

Buzzi et al. Meteorol. Zeitschrift 13: 91-97

Chiao et al. Mon. Weather Rev. 132: 2184-2203

Davolio and Buzzi. Weather and Forecasting 19: 855-871

*Flamant et al. Q. J. R. Meteorol. Soc. 130: 1275-1303

Frioud et al. Meteorol. Zeitschrift 13: 175-181

Gheusi and Davies. Q. J. R. Meteorol. Soc. 130: 2125-2152

Gohm and Mayr. Q. J. R. Meteorol. Soc. 130: 449-480

${ }^{*}$ Gohm et al. Mon. Weather Rev. 132: 78-102

Grubišić. Q. J. R. Meteorol. Soc. 130: 2571-2603

Häberli et al. Meteorol. Zeitschrift 13: 109-121

Hoinka and Zängl. Mon. Weather Rev. 132: 1860-1867

Ivatek and Tudor. Meteorol. Zeitschrift 13: 99-108

Jiang and Doyle. J. Atmos. Sci. 61: 2249-2266

Keil and Cardinali. Q. J. R. Meteorol. Soc. 130: 2827-2849

Kirshbaum and Durran. J. Atmos. Sci. 61: 682-698

*Lascaux et al. Meteorol. Zeitschrift 13: 49-54

* Mayr et al. Meteorol. Atmos. Phys. 86: 99-119

Miglietta and Buzzi. Q. J. R. Meteorol. Soc. 130: 1749-1770

Pradier et al. Meteorol. Atmos. Phys. 87: 197-218

Rakovec et al. Meteorol. Zeitschrift 13: 83-90

*Rotach et al. Bull. Am. Meteorol. Soc. 85: 1367-1384

Smith. Q. J. R. Meteorol. Soc. 130: 1305-1325

Soula et al. J. Geophys. Res. 109: D02101, 1-13

Stein. Q. J. R. Meteorol. Soc. 130: 481-502

*Vogt and Jaubert. Meteorol. Zeitschrift 13: 165-174

Vrhovec et al. Meteorol. Atmos. Phys. 86: 15-29
Vrhovec et al. Meteorol. Zeitschrift 13: 201-208

Walser and Schär. J. Hydrol. 288: 57-73

Walser et al. Mon. Weather Rev. 132: 560-577

Weigel and Rotach. Q. J. R. Meteorol. Soc. 130: 2605-2627

*Weissmann et al. Mon. Weather Rev. 132: 2684-2697

Žagar et al. Meteorol. Atmos. Phys. 85: 187-204

*Zängl et al. (a). Mon. Weather Rev. 132: 368-389

Zängl et al. (b). Meteorol. Zeitschrift 13: 69-76

*Zängl et al. (c). Meteorol. Atmos. Phys. 86: 213-243

Zängl. Q. J. R. Meteorol. Soc. 130: 1857-1875

\section{5}

Barstad and Smith. J. Hydrometeorol. 6: 85-99

*Bock et al. Q. J. R. Meteorol. Soc. 131: 3013-3036

Chen and Lin. J. Atmos. Sci. 62: 331-350

Chen and Lin. Meteorol. Atmos. Phys. 88: 1-21

d'Aulerio et al. Atmos. Chem. Phys. 5: 1301-1310

*de Wekker et al. Environ. Fluid Mech. 5: 35-62

Faccani and Ferretti. Q. J. R. Meteorol. Soc. 131: 21-42

Ferretti and Faccani. Q. J. R. Meteorol. Soc. 131: 43-61

Fuhrer and Schär. J. Atmos. Sci. 62: 2810-2828

Girard et al. Mon. Weather Rev. 133: 1463-1477

Guenard et al. Boundary-Layer Meteorol. 115: 263-288

Houze and Medina. J. Atmos. Sci. 62: 3599-3623

*Jaubert et al. Q. J. R. Meteorol. Soc. 131: 1339-1361

Jiang and Doyle. Geophys. Res. Lett. 32: L17807, 1-5

Jiang et al. Q. J. R. Meteorol. Soc. 131: 675-701

Lin et al. Mon. Weather Rev. 133: 2227-2245

Medina et al. J. Atmos. Sci. 62: 3580-3598

Nuret et al. Q. J. R. Meteorol. Soc. 131: 2769-2793

Pujol et al. Q. J. R. Meteorol. Soc. 131: 2795-2819

\section{6}

Asencio and Stein. Q. J. R. Meteorol. Soc. 132: 297-316

Boudevillain et al. J. Hydrol. 7: 178-189

Bousquet and Smull. Q. J. R. Meteorol. Soc. 132: 2393-2413

${ }^{*}$ Chow et al. J. Appl. Meteorol. 45: 63-86

Doyle and Jiang. Q. J. R. Meteorol. Soc. 132: 1877-1905

${ }^{*}$ Drobinski et al. Meteorol. Atmos. Phys. 92: 285-306

Flamant et al. Q. J. R. Meteorol. Soc. 132: 3035-3058

Germann et al. Q. J. R. Meteorol. Soc. 132: 1669-1692

Guénard et al. Q. J. R. Meteorol. Soc. 132: 757-777

*Guidard et al. Meteorol. Atmos. Phys. 92: 161-173

Häberli. Q. J. R. Meteorol. Soc. 132: 2827-2852

Hoggarth et al. Mon. Weather Rev. 134: 3336-3354

Hohenegger et al. Mon. Weather Rev. 134: 2095-2107

*Hoinka et al. Q. J. R. Meteorol. Soc. 132: 2853-2860

Jiang et al., J. Atmos. Sci 63: 617-633

Lascaux et al. Q. J. R. Meteorol. Soc. 132: 1907-1926

Martius et al. Int. J. Climatol. 26: 1149-1164

Reeves and Lin. J. Atmos. Sci. 63: 2567-2584

${ }^{*}$ Richner et al. Meteorol. Atmos. Phys. 92: 255-284

Smith et al., J. Atmos. Sci 63: 774-781

*Smith et al. Q. J. R. Meteorol. Soc. 132: 1467-1487

*Weigel et al. J. Appl. Meteorol. 45: 87-107

Žagar et al. Tellus A 58: 445-455

*Zängl and Gohm. Meteorol. Atmos. Phys. 93: 79-95

Zängl and Vogt. Meteorol. Zeitschrift 15: 179-186 


\section{Appendix C}

Educational output

Research programmes which integrate university institutes tend to have a considerable educational component, especially through the conduct of $\mathrm{PhD}$ projects. In
Table C I, the country code refers to the university or research institute where the work was undertaken, and not necessarily to the author's nationality. The titles reflect the languages used.

Table C I. MAP-related dissertations sorted by year of their completion and alphabetically by author.

\begin{tabular}{llll}
\hline Year & No. & $\begin{array}{l}\text { Author Surname, first } \\
\text { name (country) }\end{array}$ & Thesis title \\
\hline 1997 & 01 & Fehlmann, René (CH) & Dynamics of seminal PV elements. \\
\hline 1998 & 02 & Leutbecher, Martin (D) & $\begin{array}{l}\text { Die Ausbreitung orographisch angeregter Schwerewellen in die } \\
\text { Stratosphäre - Lineare Theorie, idealisierte und realitätsnahe numerische } \\
\text { Simulation. }\end{array}$ \\
\hline 1999 & 03 & Sprenger, Michael (CH) & Rotational aspects of atmospheric flow past Alpine-scale orography. \\
\hline 2000 & 04 & Cosma, Stéphanie (F) & $\begin{array}{l}\text { Simulations numériques à haute résolution de systèmes précipitants intenses sur } \\
\text { orographie complexe. } \\
\text { La valutazione dell'evapotraspirazione in ambienti montani. } \\
\text { Numerische Simulation von Starkniederschlagsereignissen mit mesoskaligen } \\
\text { Wettervorhersagemodellen. } \\
\text { The effects of the soil, vegetation and atmosphere interactions in hydrological } \\
\text { flood models. } \\
\text { Airborne differential absorption Lidar for water vapour measurements in the upper } \\
\text { troposphere and lower stratosphere in the spectral region around } 940 \text { nm. } \\
\text { Reconstruction and analysis of mesoscale precipitation in the Alps for the } \\
\text { twentieth century. } \\
\text { The Alpine precipitation climate: Evaluation of a high-resolution analysis scheme } \\
\text { using comprehensive rain-gauge data. }\end{array}$ \\
\hline 09 & Keil, Christian (D) & Montaldo, Nicola (I) & Schmidli, Jürg (CH) \\
\hline
\end{tabular}

200111 Gheuzi, François (F)

Analyses eulériennes et lagrangiennes des systèmes quasi-stationnaires sur les Alpes.

12 Jasper, Karsten $(\mathrm{CH})$

Runoff and flash flooding in the Ticino region.

13 Jiang, Qingfang (USA)

Some theoretical aspects of orographic precipitation.

200214 Gaberšek, Saša (USA)

The dynamics of gap flow over idealized topography.

15 Lothon, Marie (F)

Etude phénomènologique du foehn dans la vallée du Rhin au cours de l'expérience MAP.

16 Pradier, Stéphanie $(\mathrm{F}) \quad$ Charactéristiques de l'écoulement et des précipitations observés durant MAP: Une analyse par radar et simulation numérique.

17 Tabary, Pierre (F) Observations radar de systèmes précipitants orographiques pendant l'expérience MAP.

18 Walser, André $(\mathrm{CH})$

Predictability issues in meso- $\beta$ scale numerical weather forecasting.

19 Weiss, Alexandra $(\mathrm{CH})$

Determination of stratification and turbulence of the atmospheric surface layer for different types of terrain by optical scintillometry.

20 de Wekker, Stephan (CAN) Structure and morphology of the convective boundary layer in mountainous terrain.

21 Zappa, Massimiliano $(\mathrm{CH})$ Multiple-response verification of a distributed hydrological model at different spatial scales.

200322 Beffrey, Guillaume (F)

23 Chiao, Sen (USA)

24 Gohm, Alexander (A)

25 van Gorsel, Eva $(\mathrm{CH})$

26 Manfrin, Massimiliano (I)

27 Rucker, Magdalena (CAN)
Etude de l'aspect tridimensionnel du foehn dans la haute vallée du Rhin. The dynamics of orographic precipitation: A mesoscale modeling perspective. Contributions to the dynamics of south föhn: A gap flow study during the Mesoscale Alpine Programme.

Aspects of flow characteristics and turbulence in complex terrain: results from the MAP-RIVIERA project.

Meccanismi di generazione di onde di gravità atmosferiche e loro interazioni con il mare e le precipitazioni.

Observational and numerical study of daytime flows in an alpine valley. 
Table C I. (Continued).

\begin{tabular}{|c|c|c|c|}
\hline Year & No. & $\begin{array}{l}\text { Author Surname, first } \\
\text { name (country) }\end{array}$ & Thesis title \\
\hline & 28 & Seity, Yann (F) & $\begin{array}{l}\text { Relations entre activités d'éclairs, microphysique et dynamique au sein d'orages } \\
\text { européens. }\end{array}$ \\
\hline & 29 & Thurman, James A (USA) & $\begin{array}{l}\text { Numerical studies of synoptic and mesoscale environments conducive to heavy } \\
\text { rainfall in tropical and extratropical systems. }\end{array}$ \\
\hline & 30 & Zängl, Günther (D) & $\begin{array}{l}\text { Untersuchung der Dynamik des alpinen Föhns sowie einiger ausgewählter } \\
\text { Talwindsysteme mit Hilfe numerischer Simulationen (Habilitation). }\end{array}$ \\
\hline \multirow[t]{5}{*}{2004} & 31 & d'Aulerio, Paola (I) & $\begin{array}{l}\text { Raman LIDAR water vapor measurements: analysis of dry intrusions in the free } \\
\text { troposphere. }\end{array}$ \\
\hline & 32 & Blahak, Ulrich (D) & $\begin{array}{l}\text { Analyse des Extinktionseffektes bei Niederschlagsmessungen mit einem C-Band } \\
\text { Radar anhand von Simulation und Messung. }\end{array}$ \\
\hline & 33 & Chow, Fotini K. (USA) & $\begin{array}{l}\text { Subfilter-scale modeling for large-eddy simulations of the atmospheric boundary } \\
\text { layer over complex terrain. }\end{array}$ \\
\hline & 34 & James, Curtis N. (USA) & Radar observations of orographic precipitation. \\
\hline & 35 & Vergeiner, Johannes (A) & $\begin{array}{l}\text { South föhn studies and a new föhn classification scheme in the Wipp and Inn } \\
\text { valleys. }\end{array}$ \\
\hline \multirow[t]{6}{*}{2005} & 36 & Barontini, Stefano (I) & Processi di infiltrazione in suoli a permeabilità decrescente. \\
\hline & 37 & Fuhrer, Oliver $(\mathrm{CH})$ & $\begin{array}{l}\text { From advection to convection: Dynamical issues in high-resolution modeling of } \\
\text { atmospheric flows past topography. }\end{array}$ \\
\hline & 38 & Lascaux, Franck (F) & $\begin{array}{l}\text { Simulations numériques d'épisodes de précipitations intenses documentés lors de } \\
\text { la campagne MAP. }\end{array}$ \\
\hline & 39 & Marić, Tomislav (USA) & The applicability of hydraulic theory to gap winds observed in the Wipp valley. \\
\hline & 40 & Medina-Valles, Socorro (USA) & Orographic enhancement of mid-latitude cyclone precipitation. \\
\hline & 41 & Weigel, Andreas (CH) & On the atmospheric boundary layer over highly complex topography. \\
\hline \multirow[t]{3}{*}{2006} & 42 & Häberli, Christian (A) & $\begin{array}{l}\text { The comprehensive Alpine radiosonde dataset (CALRAS): Contribution to the } \\
\text { regional climate diagnostic based on upper-air soundings 1957-1999. }\end{array}$ \\
\hline & 43 & Hohenegger, Cathy $(\mathrm{CH})$ & Dynamical analysis of atmospheric predictability in cloud-resolving models. \\
\hline & 44 & Pujol, Olivier (F) & $\begin{array}{l}\text { Etude microphysique des nuages et des précipitations par radar polarimétrique et } \\
\text { simulation numérique. }\end{array}$ \\
\hline 2007 & 45 & Reeves, Heather D. (USA) & $\begin{array}{l}\text { Mesoscale disturbances and orographic precipitation distribution: Three special } \\
\text { case scenarios. }\end{array}$ \\
\hline
\end{tabular}

\section{Appendix D}

List of acronyms

ALADIN Aire Limitée Adaption Dynamique et

\begin{tabular}{|c|c|}
\hline & lévelopment International \\
\hline ALPEX & Alpine Experiment \\
\hline AMI & Aeronautica Militare, Italy \\
\hline ARSO & Slovenian Environmental Agency \\
\hline BOLAM & Bologna Limited-Area Model \\
\hline COAMPS & $\begin{array}{l}\text { Coupled Ocean-Atmosphere Mesoscale } \\
\text { Prediction System }\end{array}$ \\
\hline CNES & $\begin{array}{l}\text { Centre National d'Études } \\
\text { France }\end{array}$ \\
\hline CNR & $\begin{array}{l}\text { Consiglio Nazionale delle } \\
\text { Italy }\end{array}$ \\
\hline CNRS & $\begin{array}{l}\text { Centre National de la Recherche Scien- } \\
\text { tifique, France }\end{array}$ \\
\hline CSCS & Swiss National Supercomputing Centre \\
\hline DFG & Deutsche Forschungsgemeinschaft \\
\hline DHMZ & $\begin{array}{l}\text { Croatian Meteorological and Hydrological } \\
\text { Service }\end{array}$ \\
\hline
\end{tabular}

DLR Deutsches Zentrum für Luft- und Raumfahrt

D-PHASE Demonstration of Probabilistic Hydrological and Atmospheric Simulation of flood Events in the Alpine region

DWD Deutscher Wetterdienst

ECMWF European Centre for Medium-range Weather Forecasts

EDF Electricité de France

ETH Eidgenössische Technische Hochschule, Switzerland

EU European Union

EUMETNET Network of European Meteorological Services

EUMETSAT Europe's Meteorological Satellite Organisation

FASTEX Fronts and Atlantic Storm-Track Experiment

Fed.Min. Federal Ministries: Science \& Technology and Environment, Youth \& Family, Austria 
$\begin{array}{ll}\text { FWF } & \begin{array}{l}\text { Fonds zur Förderung der Wissenschaftli- } \\ \text { chen Forschung, Austria }\end{array} \\ \text { GARP } & \text { Global Atmospheric Research Program } \\ \text { GATE } & \text { GARP Atlantic Tropical Experiment } \\ \text { GOP } & \begin{array}{l}\text { General Observation Period } \\ \text { HERA }\end{array} \\ & \text { Heavy precipitation in the Alpine } \\ \text { Region }\end{array}$

IMPROVE Improvement of Microphysical Parameterization through Observational Verification Experiment

IOP Intensive Observing Period

JOSS Joint Office of Scientific Support, USA

MAP Mesoscale Alpine Programme

MC2 Mesoscale Compressible Community Model, Canada

MSC Meteorological Service of Canada

MSG Meteosat Second Generation

NASA National Aeronautics and Space Administration, USA

NCAR National Center for Atmospheric Research, USA

NERC Natural Environment Research Council, UK

NOAA National Oceanographic and Atmospheric Administration, USA

NRC National Research Council, Canada

NRL Naval Research Laboratory, USA

NSF National Science Foundation, USA

NWP Numerical weather prediction

ONR Office of Naval Research, USA

PSU/NCAR Pennsylvania State University/National Center for Atmospheric Research, USA

PYREX Pyrenées Experiment

RAPHAEL Runoff and atmospheric processes for flood hazard forecasting and control

SNF Schweizerischer Nationalfonds zur

Föderung der Wissenschaften

$\begin{array}{ll}\text { THORPEX } & \text { Special Observing Period } \\ \text { The Observing System Research and Pre- }\end{array}$ dictability Experiment

WMO World Meteorological Organization

WWRP World Weather Research Programme

\section{References}

Bacchi B, Ranzi R, Richard E (eds.) 2003. Hydrometeorological processes and floods in the Alps. Hydrol. Earth System Sci. 7: 783-948.

Benoit R, Schär C, Binder P, Chamberland S, Davies HC, Desgagne M, Girard C, Keil C, Kouwen N, Lüthi D, Maric D, Müller E, Pellerin P, Schmidli J, Schubiger F, Schwierz C, Sprenger M, Walser A, Willemse S, Yu W, Zala E. 2002. The real-time ultrafinescale forecast support during the special observing period of MAP. Bull. Am. Meteorol. Soc. 83: 85-109.

Binder P, Schär C (eds.) 1995. Mesoscale Alpine Programme - Design proposal. MeteoSwiss: Zurich. (amended 2nd edition, 1996, including hydrological applications); available at http://www.map.meteoswiss.ch/map-doc/proposal.htm.

Bjerknes J. 1919. On the structure of moving cyclones. Geophys. Publ. 1(2): 1-8; Mon. Weather Rev. 47: 95-99.

Bjerknes V. 1904. Das Problem der Wettervorhersage, betrachtet vom Standpunkte der Mechanik und der Physik. Meteorol. Zeitschrift 21: 1-7; English transl. Mintz Y in The life cycles of extratropical cyclones. Shapiro MA, Grønås S (eds.) Amer. Meteorol. Soc. 1999. $1-4$.

Bougeault P, Benech B, Bessemoulin P, Carissimo B, Jansa Clar A, Pelon J, Petitdidier M, Richard E. 1997. PYREX: A summary of findings. Bull. Am. Meteorol. Soc. 78: 637-650.

Bougeault P, Binder P, Buzzi A, Dirks R, Houze R, Kuettner J, Smith RB, Steinacker R, Volkert H. 2001. The MAP Special Observing Period. Bull. Am. Meteorol. Soc. 82: 433-462.

Bougeault P, Richard E, Roux F. 2002. 'Le Mesoscale Alpine Programme MAP'. La lettre du changement global No. 13, CNRS: SaintMartin-d'Hères; available at http://www.cnrs.fr/cw/dossiers/dosclim/ biblio/pigb13/05_mesoscale.htm.

Bougeault P, Houze RA, Rotunno R, Volkert H (eds.) 2003. MAP SOP special issue. Q. J. R. Meteorol. Soc. 129: 341-899.

Browning KA, Chalon JP, Thorpe AJ (eds). 1999. FASTEX special issue. Q. J. R. Meteorol. Soc. 125: 3129-3599.

Chong M, Georgis JF, Bousquet O, Brodzik SR, Burghart C, Cosma S, Germann U, Gouget V, Houze RA, James CN, Prieur S, Rotunno R, Roux F, Vivekanandan J, Zeng ZX. 2000. Real-time wind synthesis from Doppler radar observations during the Mesoscale Alpine Programme. Bull. Am. Meteorol. Soc. 81: 2953-2962.

Drobinski P, Steinacker R, Richner H, Baumann-Stanzer K, Beffrey G, Berger H, Chimani B, Dabas A, Dorninger M, Dürr B, Flamant C, Frioud M, Grohn I, Gubser S, Gutermann T, Häberli C, Aller-Scharnhorst H, Jaubert G, Lothon M, Mitev V, Pechinger U, Piringer M, Ratheiser M, Ruffieux D, Seiz G, Spazierer M, Tschanett S, Vogt S, Werner R, Zängl G. 2007. Föhn in the Rhine valley during MAP: A review of its multiscale dynamics in complex valley geometry. Q. J. R. Meteorol. Soc. 133: 897-916.

Friedman RM. 1989. Appropriating the weather: Vilhelm Bjerknes and the construction of a modern meteorology. Cornell University Press.

Georgelin M, Bougeault P, Black T, Brzovic N, Buzzi A, Calvo J, Casse V, Desgagne M, El-Khatib R, Geleyn JF, Holt T, Hong SY, Kato T, Katzfey J, Kurihara K, Lacroix B, Lalaurette F, Lemaitre Y, Mailhot J, Majewski D, Malguzzi P, Masson V, McGregor J, Minguzzi E, Paccagnella T, Wilson C. 2000. The second COMPARE exercise: A model intercomparison using a case of a typical mesoscale orographic flow, the PYREX IOP 3. Q. J. R. Meteorol. Soc. 126: $991-1029$.

Hide R, White PW (eds.) 1980. Orographic effects in planetary flows. GARP Publ. No. 23, World Meteorol. Organization: Geneva.

Hoinka KP, Davies HC. 2007. Upper-tropospheric flow features and the Alps: An overview. Q. J. R. Meteorol. Soc. 133: 847-865.

Houze RA, Kuettner JP, Smith RB. 1998. Mesoscale Alpine Programme: US overview document and experiment design. Joint Office for Science Support, UCAR: Boulder; available at http://www.joss.ucar.edu/joss_psg/projects/map/.

ICSU. 2006. ICSU and Climate Science, 1962-2006 and beyond: From GARP to IPCC. Internat. Council for Science, Paris. available at http://www.icsu.org/10_icsu75/PDF/Climate_Change.pdf.

Kuettner J. 1986. The aim and conduct of ALPEX. Pp. 3-13 in Scientific results of the Alpine Experiment (ALPEX). WMO-ICSU Technical Document No. 108, World Meteorol. Organization: Geneva.

LeMone MA. 2003. What we have learned about field programs. Pp. 25-35 in Cloud Systems, Hurricanes, and the Tropical Rainfall Measuring Mission (TRMM). Tao WK (ed), Meteorol. Monogr. 29 Amer. Meteorol. Soc: Boston.

Lynch P. 2002. Weather forecasting: From woolly art to solid science. Pp. 106-119 in Meteorology at the Millennium. Pearce RP (ed.) Academic Press.

MAP. 1994-2005. MAP Newsletters. 20 issues available at: http://www.map.meteoswiss.ch/map-doc/newsletter.htm.

Mayr GJ, Armi L, Gohm A, Zängl G, Durran DR, Flamant C, Gaberšek S, Mobbs S, Ross A, Weissmann M. 2007. Gap flows: Results from the Mesoscale Alpine Programme. Q. J. R. Meteorol. Soc. 133: 881-896.

Ranzi R, Zappa M, Bacchi B. 2007. Hydrological aspects of the Mesoscale Alpine Programme: Findings from field experiments and simulations. Q. J. R. Meteorol. Soc. 133: 867-880.

Richard E, Buzzi A, Zängl G. 2007. Quantitative precipitation forecasting in the Alps: The advances achieved by the Mesoscale Alpine Programme. Q. J. R. Meteorol. Soc. 133: 831-846.

Rossa A, Schwierz C, Furger M (eds) 2004. Peer reviewed MAP contributions to the $27^{\text {th }}$ International Conference on Alpine Meteorology, Brig, Switzerland, May 2003 (ICAM-2003). Meteorol. Z. 13: 3-252.

Rossa A. 2007. The Mesoscale Alpine Programme of the National Weather Services - Final report of an optional EUMETNET 
programme. Arbeitsberichte MeteoSchweiz No. 215; available from http://www.meteoschweiz.ch/web/de/forschung/publikationen/ meteoschweiz_publikationen/arbeitsberichte.html also http://www. eumetnet.eu.org.

Rotach MW, Zardi D. 2007. On the boundary-layer structure over highly complex terrain: Key findings from MAP. Q. J. R. Meteorol. Soc. 133: 937-948.

Rotach MW, Calanca P, Graziani G, Gurtz J, Steyn DG, Vogt R, Andretta M, Christen A, Cieslik S, Connolly R, de Wekker SFJ, Galmarini S, Kadygrov EN, Kadygrov V, Miller E, Neininger B, Rucker M, van Gorsel E, Weber H, Weiss A, Zappa M. 2004 Turbulence structure and exchange processes in an Alpine Valley: The Riviera project. Bull. Am. Meteorol. Soc. 85: 1367-1385.

Rotunno R, Houze RA. 2007. Lessons on orographic precipitation from the Mesoscale Alpine Programme. Q. J. R. Meteorol. Soc. 133: $811-830$.

Schär C. 2002. Mesoscale mountains and the larger-scale atmospheric dynamics: A review. Pp. 106-119 in Meteorology at the Millennium. Pearce RP (ed.) Academic Press.

Schwarb M, Daly C, Frei C, Schär C. 2001. Mean annual and seasonal precipitation in the European Alps 1971-1990. Plates 2.6 and 2.7 of Hydrologischer Atlas der Schweiz, Bundesamt für Wasser und Geologie: Bern.

Shaw WN. 1895. The motions of clouds considered with reference to their mode of formation. Q. J. R. Meteorol. Soc. 21: 166-180.

Shaw WN. 1934. The march of meteorology: Random recollections. Q. J. R. Meteorol. Soc. 60: 101-120.
Shaw WN, Lempfert RGK. 1906. The life history of surface air currents: A study of the surface trajectories of moving air. Meteorol. Office Memoir 174, Met Office: London; Reprinted in Pp. 15-131 of Selected Meteorological Papers of Sir Napier Shaw 1955. MacDonald \& Co: London.

Smith RB, Doyle JD, Jiang Q, Smith SA. 2007. Alpine gravity waves: Lessons from MAP regarding mountain wave generation and breaking. Q. J. R. Meteorol. Soc. 133: 917-936.

Staley R. 2006. Fog, dust and rising air. Pp. 93-113 in Intimate universality: Local and global themes in the history of weather and climate. Fleming JR, Jankovic V, Coen DR (eds.) Science History Publications: Sagamore Beach, USA.

Steinacker R. 1998. 'Strawman scenario for MAP-SOP events'. MAP Newsletter 10: 2-5, MeteoSwiss: Zurich

Stoelinga M, Hobbs PV, Mass CF, Locatelli JD, Colle BA, Houze RA, Rango AL, Bond NA, Smull BF, Rasmussen RM, Thompson G, Coleman BR. 2003. Improvement of microphysical parameterization through observational verification experiment. Bull. Am. Meteorol. Soc. 84: 1807-1826.

Volkert H (ed.) 2000. Heavy precipitation in the Alpine region (HERA). Meteorol. Atmos. Phys. 72: 71-270.

Volkert H, Binder P, Micheletti S, Rakovec J, Schär C, Steinacker R. 1993. 'Mesoscale Alpine Project (MAP)'. Pp. 23-29 of ALPEX Regional Bull. 21, MeteoSwiss: Zurich. Available at http://www.pa. op.dlr.de/map2002/map-proposal-93.pdf.

Woods A. 2006. Medium-range weather prediction: The European approach. Springer: Berlin. 